Alicja Melzacka

CIAP Kunstverein w Hasselt, Belgia

ORCID: 0000-0001-8603-3040

\title{
Architektura w śródmieściu Gdyni po 1989 r. wobec tradycji modernistycznej
}

DOI: https://doi.org/10.26881/porta.2018.17.09

Celem niniejszego artykułu jest dokonanie charakterystyki wybranych przykładów śródmiejskiej architektury powstałej w Gdyni po 1989 r., ze szczególnym uwzględnieniem jej stosunku wobec tytułowej „tradycji modernistycznej” ${ }^{1}$. W tym miejscu należy wspomnieć o dwóch wcześniejszych artykułach na ten temat - Inspiracjach międzywojennych we wspótczesnej architekturze Gdyni ${ }^{2}$ autorstwa Marii Jolanty Sołtysik oraz $O$ wspótczesnej architekturze Gdyni Iwony Joć3. Niniejszy tekst nie rości sobie prawa do wyczerpania tematu. Ze względu na ograniczoną objętość obszerniejsze wprowadzenie oraz szczegółowe omówienie każdego z obiektów nie są możliwe. Celem tej publikacji jest jedynie wskazanie pewnych powtarzalnych tendencji występujących we współczesnej architekturze Gdyni oraz zidentyfikowanie ich źródeł. Tekst może stać się przyczynkiem do dyskusji nad gdyńską architekturą - w jaki sposób nawiązuje ona do modernistycznego dziedzictwa oraz gdzie poszukuje form odmiennych, ile inspiracji czerpie z zagranicznych wzorców, a ile z - lokalnych. Zakres terytorialny niniejszego opracowania (nazywany dalej śródmieściem ${ }^{4}$ ) pokrywa się z obszarem określonym w obowiązującym Studium Uwarunkowań i Kierunków Zagospodarowania Przestrzennego Gdyni jako „obszar centrum miasta”.

Śródmieście Gdyni jest specyficznym środowiskiem dla rozwoju nowoczesnej architektury, przede wszystkim ze względu na obecność zabytkowej tkanki miejskiej. Gdynia była, obok Stalowej Woli, miastem założonym w okresie międzywojennym na surowym korzeniu, żywiołowo się rozwijającym ${ }^{6}$. Nasilona działalność budowlana

1 Tekst ten powstał w oparciu o pracę licencjacką o tym samym tytule, napisaną pod kierunkiem dr. Jacka Friedricha, obronioną w Instytucie Historii Sztuki UG w 2014 r.

2 Maria Jolanta Sołtysik, Inspiracje międzywojenne we współczesnej architekturze Gdyni, „Architektura i Urbanistyka. Zeszyty Naukowe Politechniki Poznańskiej” 2008, nr 15, s. 43-57.

3 Iwona Joć, O współczesnej architekturze Gdyni, „Pomerania. Miesięcznik regionalny” 2006, nr 1, s. 7-10.

4 Mowa tu o śródmieściu w znaczeniu potocznym, niekoniecznie pokrywającym się z administracyjnymi granicami dzielnicy Śródmieście.

5 Studium Uwarunkowań i Kierunków Zagospodarowania Przestrzennego Gdyni. Załącznik nr 2 do uchwały nr XXXVIII/799/14 Rady Miasta Gdyni z dnia 15 stycznia 2014 r., Biuro Planowania Przestrzennego Miasta Gdynia, Gdynia 2014, http://www.gdynia.pl/g2/2014_01/79177_fileot. jpg [dostęp: 25.03.2014].

6 Międzywojenna tendencja do fundowania nowych ośrodków miejskich, o często eksperymentalnym charakterze, zauważalna była w wielu europejskich krajach, por. Planting New Towns 
w latach dwudziestych i trzydziestych XX w., spowodowana założeniem i rozbudową portu, doprowadziła do powstania w ciągu zaledwie dwóch dekad gęstej tkanki miejskiej o zróżnicowanej formie architektonicznej. W drugiej połowie lat dwudziestych XX w. na architekturę gdyńską, początkowo głównie infrastrukturę portową, zaczął oddziaływać zachodni funkcjonalizm ${ }^{7}$. Twórcy budynków o funkcji mieszkalnej i reprezentacyjnej potrzebowali czasu na zaadaptowanie nowych form, przechodząc przez etapy pośrednie łączące tradycję z nowoczesnością. Swego rodzaju wizytówką miasta stały się opływowe formy drugiej połowy lat trzydziestych ${ }^{8}$. Nazywano je „stylem okrętowym" i prawdopodobnie ze względu na tego rodzaju asocjacje zyskały znaczną popularność.

Uniwersalny i ponadnarodowy charakter modernizmu sprawia, że podobnej stylistyki szukać można zarówno w Polsce, jak i za granicą. Z jednej strony można więc dostrzec wyraźne podobieństwa architektury Gdyni do architektury Łodzi ${ }^{9}$ lub tzw. architektury luksusowej lat trzydziestych, powstającej w Warszawie, Krakowie czy Katowicach ${ }^{10}$. Z drugiej zaś strony potencjalnych źródeł inspiracji dla architektury gdyńskiej należy szukać, na co wskazuje Sołtysik, na Zachodzie, przede wszystkim w Niemczech, Francji i Holandii, zwłaszcza w realizacjach takich przedstawicieli stylu międzynarodowego, jak Le Corbusier czy Erich Mendelsohn ${ }^{11}$. Podobne rozwiązania architektoniczne można dostrzec także w modernistycznej architekturze Białego Miasta, czyli Tel Awiwu, oraz w amerykańskiej Streamline Moderne $e^{12}$, wykorzystującej m.in. marynistyczne formy nawiązujące do nowoczesnych transatlantyków, kursujących również między portem w Gdyni a wybrzeżem Stanów Zjednoczonych.

Narodziny modernizmu w Gdyni przypadły na czas, gdy architektura polska weszła w kolejną fazę poszukiwań narodowego stylu ${ }^{13}$ - niepodległa Rzeczpospolita potrzebowała nowych form wyrazu i to właśnie nad Bałtykiem miała się narodzić

in Europe in the Interwar Years: Experiments and Dreams for Future Societies, red. Helen Meller, Heleni Porfyriou, Newcastle upon Tyne 2016.

7 Maria Jolanta Sołtysik, Na styku dwóch epok. Architektura gdyńskich kamienic, Gdynia 2003, s. 129.

8 Maria Jolanta Sołtysik, Gdynia miasto dwudziestolecia międzywojennego, urbanistyka i architektura, Warszawa 1993, s. 310 .

$9 \quad$ Por. Joanna Olenderek, Modernizm w Gdyni - modernizm w Łodzi. W poszukiwaniu odniesień stylistycznych w architekturze [w:] Modernizm w Europie. Modernizm w Gdyni. Architektura lat międzywojennych i jej ochrona, red. Maria Jolanta Sołtysik, Robert Hirsch, Gdynia 2009, s. 95-104.

10 Tadeusz S. Jaroszewski, Piękne dzielnice. Uwagi o architekturze luksusowej w Warszawie w latach trzydziestych [w]: Sztuka lat trzydziestych. Materiały Sesji Stowarzyszenia Historyków Sztuki, Niedzica, kwiecień 1988, Warszawa 1991, s. 167-202.

11 Maria Jolanta Sołtysik, Modernizm gdyński - modernizm europejski. Inspiracje i analogie [w:] Modernizm w Europie..., s. 69-79.

12 Por. Andrzej K. Olszewski, Art déco i lata trzydzieste w Ameryce a sztuka europejska, Warszawa 2013.

13 Por. Małgorzata Omilanowska, Nacjonalizm a style narodowe w architekturze europejskiej XIX i poczatku XX wieku [w:] Nacjonalizm w sztuce i historii sztuki 1789-1950, red. Dariusz Konstantynów, Robert Pasieczny, Piotr Paszkiewicz, Warszawa 1998.

Architektura w śródmieściu Gdyni... 
Alicja nowa, polska tożsamość narodowa. Gdynia miała szczególne znaczenie dla Melzacka kraju, przede wszystkim ze względu na usytuowanie geopolityczne. Budowa portu stała się więc sprawą narodową pierwszej wagi, od której zależała niezależność ekonomiczna Polski. Andrzej Szczerski określa Gdynię jako miejsce, „W którym modernizacja okazywała się nie utopijnym projektem, ale rzeczywistością", i umieszcza ten fenomen w szerszym kontekście, powstałej po zakończeniu pierwszej wojny światowej „Nowej Europy”"

Architektura międzywojennej Gdyni należała do „ikonosfery Polski morskiej"15. Stanowiła jedno z narzędzi propagandy wizualnej praktykowanej przez rząd, której celem było zaszczepienie w społeczeństwie tzw. „patriotyzmu morskiego", a co za tym idzie pozyskanie społecznej akceptacji dla polityki morskiej rządu ${ }^{16}$. Funkcję tę pełniły nie tylko ambitne wizje o dużym ładunku symbolicznym, np. projekt Dzielnicy Reprezentacyjnej ${ }^{17}$, lecz także otaczająca mieszkańców architektura. Język modernizmu miał wskazywać na ciągłe dążenie miasta do postępu, a elementy „okrętowe” - podkreślać bliskość morza. Jak pisze Szczerski, „gdyński modernizm [...] unikał [...] awangardowego radykalizmu, a modernistyczne formy ceniono za ich funkcjonalność i estetykę wyrażającą nową tożsamość miasta” ${ }^{18}$. Mit „białej Gdyni”, „bramy na świat”, stolicy „Polski morskiej” szybko ugruntował się w całym kraju i wydaje się, że funkcjonuje do dziś, przyczyniając się do pewnej mitologizacji wszystkiego, co związane jest $\mathrm{z}$ rozwojem miasta w okresie międzywojennym.

Zmiany ustrojowe 1989 r. wywarły decydujący wpływ na przyszły rozwój organizujących się i powstających wówczas na nowo państw. Dla Polski była to sytuacja zbliżona nieco do tej z $1918 \mathrm{r}$. W obu wypadkach osłabiony kraj otrzymywał nagle możliwość rozwoju, lecz równocześnie napotykał liczne przeszkody, m.in. niedobór kapitału dla zaspokojenia pilnych potrzeb. We wszystkich krajach dawnego bloku wschodniego głównymi mechanizmami były prywatyzacja w opozycji do dawnej własności państwowej, decentralizacja przeciwstawiana monocentryzmowi oraz komercjalizacja i globalizacja w odpowiedzi na autarkię i izolację zarówno pod względem gospodarczym, jak i kulturowym. Wraz ze środkami finansowymi napływały zachodnie wzorce kulturowe, gwałtownie zmieniała się sytuacja polityczna, społeczna

14 Andrzej Szczerski, Modernizacje. Sztuka i architektura w nowych państwach Europy Środkowo-Wschodniej 1918-1939, Łódź 2010, s. 250.

15 Małgorzata Omilanowska Propaganda wizualna „Polski morskiej” [w:] Polska nad Battykiem. Konstruowanie identyfikacji kulturowej państwa nad morzem 1918-1939, red. Dariusz Konstantynów, Małgorzata Omilanowska, Gdańsk 2012, s. 9-17, tu s. 10.

16 Ibidem, s. 10-11.

17 Pierwszy niezrealizowany projekt został sporządzony w 1938 r. pod kierunkiem Stanisława Filipkowskiego z Pracowni Projektów przy Komisariacie Rządu w Gdyni, zob. Maria Jolanta Sołtysik, Dzielnica reprezentacyjna Gdyni i jej powojenne oraz współczesne interpretacje [w:] Wplyw dorobku II Rzeczypospolitej na urbanistykę i architekture powojenna, red. Witold Czarnecki, Białystok 2013, s. 325-353.

18 Szczerski, Modernizacje..., s. 250. 
i gospodarcza ${ }^{19}$. Polityka leseferyzmu w kształtowaniu przestrzeni miejskiej doprowadziła w wielu wypadkach do powstania niezintegrowanej z otoczeniem architektury i do urbanistycznego kryzysu, zwłaszcza w ostatniej dekadzie w śródmieściu $\mathrm{XX} \mathrm{w.}{ }^{20}$ Obszar podlegający transformacji, przyciągający globalnych inwestorów nazywano wręcz „Dzikim Wschodem”21.

W Gdyni można było zaobserwować analogiczne procesy. Przemysł i transport zaczęły tracić znaczenie na rzecz sektora usług. Poważnym problemem, przed którym stanęło miasto po upadku Stoczni Gdynia SA w 2008 r., było i pozostaje nadal zagospodarowanie terenów postoczniowych i portowych. Gospodarka morska i infrastruktura portowa pełniły dawniej, oprócz funkcji ekonomicznej, funkcję kulturotwórczą ${ }^{22}$. Obecnie, w dobie przejścia od gospodarki przemysłowej do postindustrialnej, tożsamość morska, by przetrwać, musi być wciąż na nowo podbudowywana ${ }^{23}$. Może temu służyć m.in. organizowanie imprez masowych propagujących żeglarstwo czy funkcjonowanie instytucji przybliżających historię miasta i jego architektury. Funkcję komemoratywną pełni również warstwa informacyjna miasta. Ważną rolę odgrywa w dalszym ciągu modernistyczna zabudowa śródmieścia, którą Michał Graban nazywa „istotnym czynnikiem identyfikacji dla gdynian" ${ }^{24}$. Ukuto nawet osobny termin, stosowany w literaturze popularnej i internecie - styl gdyński. Nie należy zapominać, że do budowania tej tożsamości przyczynia się również architektura współczesna.

Podział śródmieścia na strefy, w oparciu o dwie różne metody klasyfikacji zaproponowane przez Barbarę Bańkowską i Piotra Lorensa ${ }^{25}$, posłużył za szkielet organizujący strukturę niniejszego opracowania. Wydzieliłam kolejno strefy: zachodnią (okołoprzystankową, wraz z okolicami ulicy Śląskiej), północną, centralną i wschodnią (zwaną Nadmorską Strefą Prestiżu Miejskiego).

Do strefy zachodniej zaliczam obszar ograniczony od Wschodu ulicą Władysława IV, rozciągający się między dwiema stacjami Szybkiej Kolei Miejskiej (SKM Gdynia Główna oraz SKM Wzgórze Świętego Maksymiliana), oraz rejon ulicy Śląskiej, który jest zalążkiem gdyńskiej dzielnicy biznesowej i ze względu

19 Por. The Post-Socialist City, Urban Form and Space Transformations in Central and Eastern Europe after Socialism, red. Kiril Stanilov, Dordrecht 2010.

20 Sławomir Gzell, Urbanistyka modernistyczna po cezurze II wojny światowej - przykłady Warszawy i Nowych Tych [w:] Wplyw dorobku II Rzeczypospolitej..., s. 36.

${ }_{21}$ William Robinson, Globalization: nine theses on our Epoch, „Race and Class” 1996, $\mathrm{nr}$ 38(2), s. 13-31, cyt. za: Kiril Stanilov, The restructuring of non-residential uses in the post-socialist metropolis [w:] The Post-Socialist..., s. 82.

22 Michał Graban, Tożsamość morska Gdyni wobec wyzwań epoki postindustrialnej [w:] Globalizacja i my. Tożsamość lokalna wobec trendów globalnych, red. Romuald Piekarski, Michał Graban, Kraków 2003, s. 271-272.

23 Por. Michał Graban, Gdynia wobec przeobrażeń cywilizacyjnych XX i XXI w., Gdynia 2012.

24 Graban, Tożsamość morska Gdyni..., s. 283.

25 Barbara Bańkowska, Urbanistyka i ja, Gdańsk 2012, s. 241-250; Piotr Lorens, Plany rozwoju przestrzennego jako kontynuacja rozwoju międzywojennej wizji, „Renowacje i Zabytki” 2010, nr 4, s. 127-131. 
Alicja na lokalizację tuż poza granicami administracyjnego Śródmieścia ma wysoki Melzacka potencjał inwestycyjny ${ }^{26}$.

Biurowiec City Arcade (ul. Śląska 21, inwestor: Chińsko-Polskie Towarzystwo Okrętowe, projekt: Stanisław Dopierała, Miljenko Dumenčić, 1997) składa się z jednej kondygnacji podziemnej i trzech nadziemnych, o zróżnicowanych gabarytach i rzucie nieregularnego wieloboku (il. 1). W elewacjach ciemne szkło i kamień skontrastowano z jasnym tynkiem i metaliczną okładziną. Charakterystycznym elementem budynku jest metaliczny „kontener”, czyli wyodrębniona część trzeciej kondygnacji o ostro ściętym narożniku wysuniętym przed lico fasady. Po jego wewnętrznej stronie umieszczono okrągłe okno w typie bulaju. Budynek oglądany z odpowiedniej perspektywy, przypomina kadłub statku. Wrażenie to potęguje niska nadbudówka na dachu.

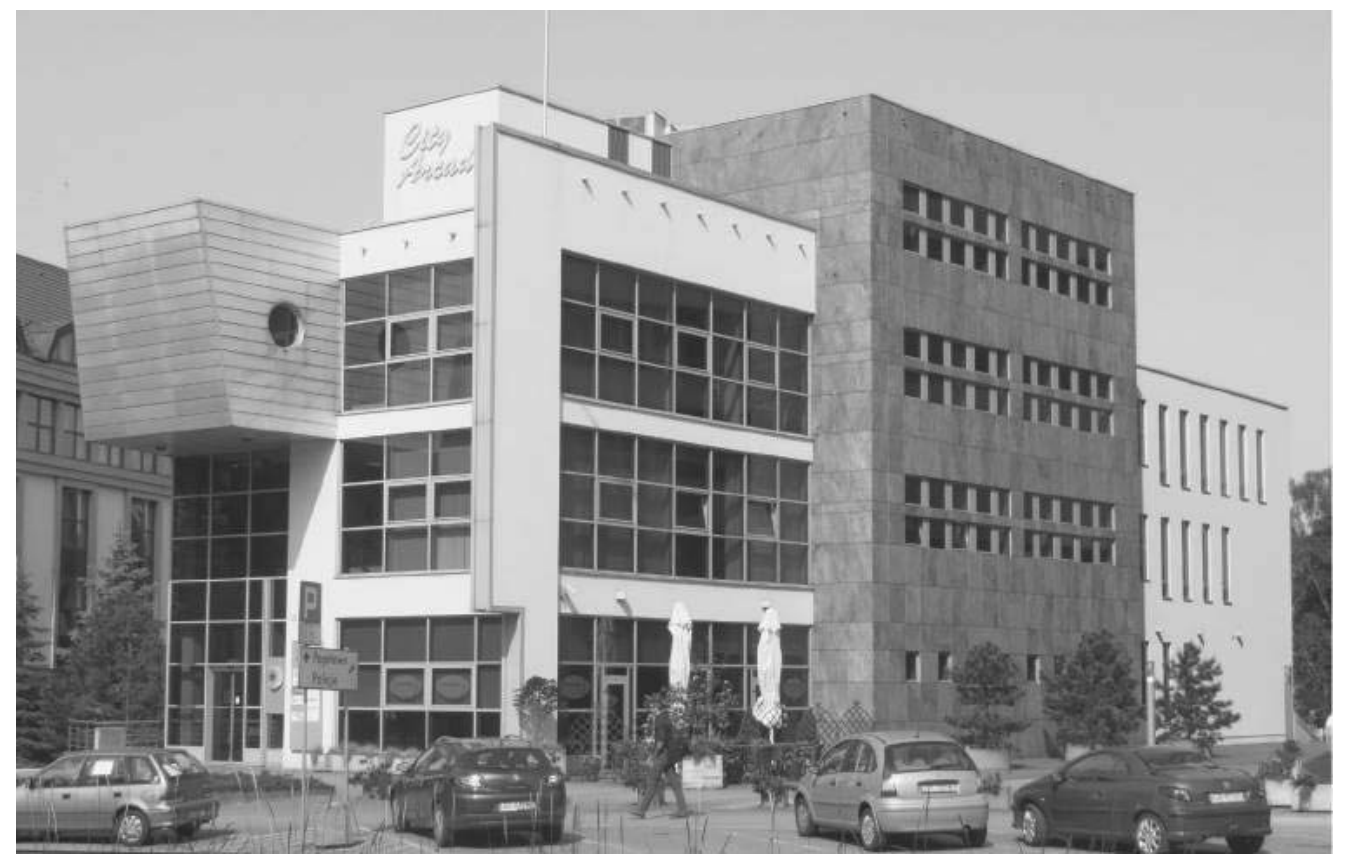

Il. 1. Gdynia, biurowiec City Arcade, ul. Śląska 21, projekt: Stanisław Dopierała, Miljenko Dumenčic, 1997, fot. Irina Gavrash

City Arcade łączy w sobie dwie różne estetyki: wydaje się, że część tylna obejmująca elewację wschodnią oraz część elewacji bocznych są adaptacją form purystycznego funkcjonalizmu, natomiast w części frontowej dopatrzyć się można dynamizujących elementów kojarzących się z architekturą konstruktywistyczną, zwłaszcza z projektami Konstantina Mielnikowa - pawilonem

26 Por. Studium uwarunkowań i kierunków, http://www.gdynia.pl/g2/2014_01/79179_fileot. pdf [dostęp: 20.03.2014], s. 17. 
sowieckim z paryskiej Wystawy Sztuki Dekoracyjnej (1925) oraz moskiewską siedzibą Klubu Zakładów im. Rusakowa (1927). Sam „kontener” nasuwa skojarzenia $z$ architekturą modułową - wygląda bowiem jak prefabrykat przyłączony do reszty budynku. $Z$ drugiej strony jego zestawienie $\mathrm{Z}$ wertykalnymi pasami Gdyni... na elewacji przypomina przeciwstawienie pionu poziomowi znane $\mathrm{z}$ „wygładzacza chmur" (Wolkenbügel) El Lissitzkiego (1924).

Biurowiec Baltic Business Center (ul. Śląska 23-25, inwestor: ILD, projekt: Miljenko Dumenčić, 1994) składa się z trzech przenikających się segmentów na rzucie prostokąta, z których środkowy, najwyższy, osiąga wysokość jedenastu kondygnacji, wyłączając parking podziemny (il. 2). Oglądany od strony fasady budynek przyjmuje formę piramidalną. Bryłę cechuje kompozycyjna równowaga oparta na grze przeciwieństw, nie tylko w strukturze, lecz także $\mathrm{w}$ warstwie wykończenia. Linie ostre łagodzone są przez elementy opływowe,

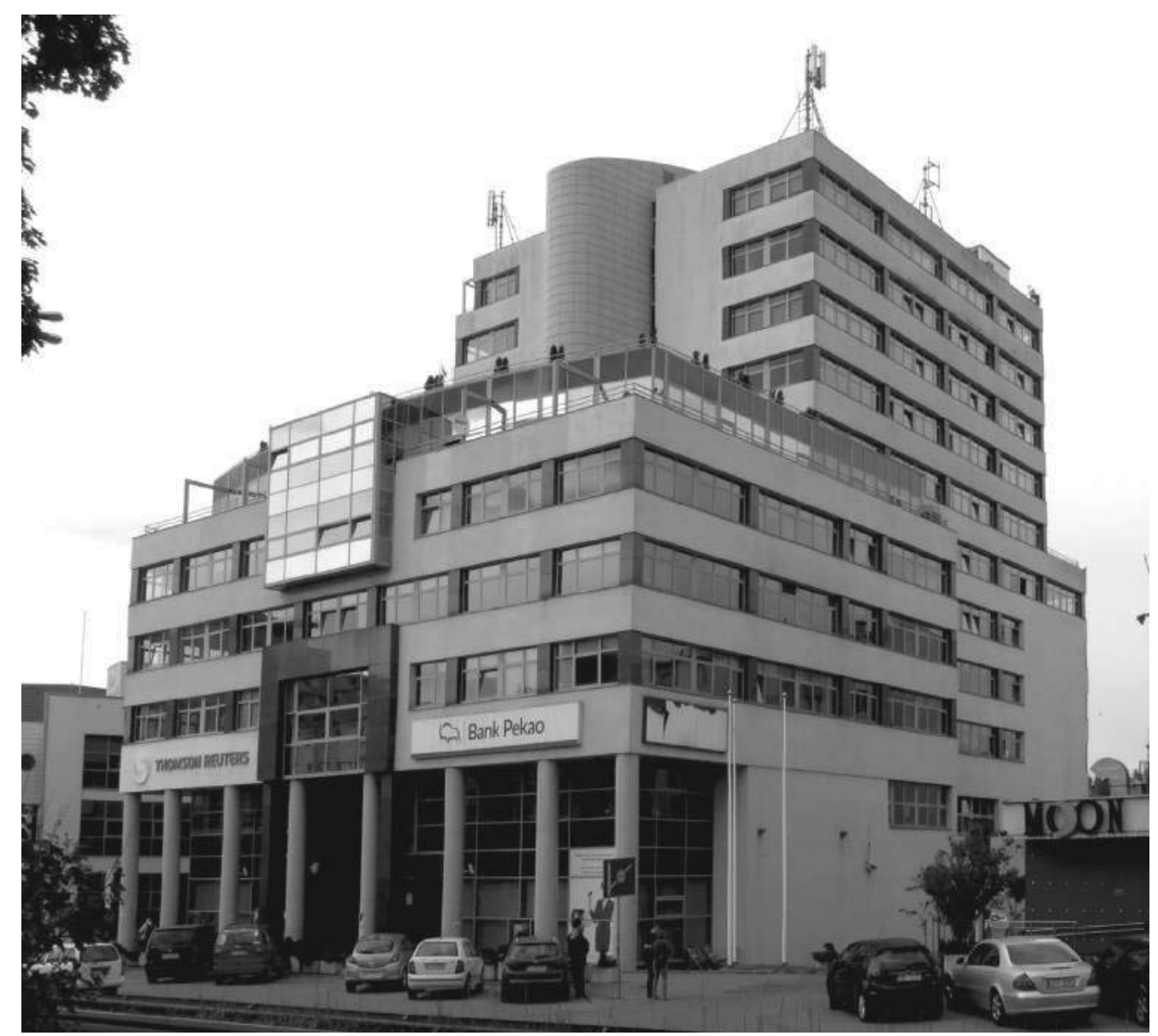

Il. 2. Gdynia, biurowiec Baltic Business Center, ul. Śląska 23-25, projekt: Miljenko Dumenčic, 1994, fot. Irina Gavrash 
Alicja a formy horyzontalne, ciążące (jak pasowy układ elewacji) są równoważone Melzacka przez elementy wertykalne, nośne (jak słupy w podcieniu). Podkreślona została tektonika budynku (wzajemne działania sił). Biały tynk skontrastowano z elementami ciemnej kamieniarki, zestawiono dwa typy szkła - refleksyjne i przezierne. W głównej fasadzie widać wpływ projektów Le Corbusiera - prostopadłościenna bryła spoczywa na słupach (pilotis). Pomimo dodania elementów zacierających nieco purystyczny charakter tej architektury (np. przeszklone elementy i wyodrębniona klatka schodowa na osi fasady) myśl przewodnia wciąż jest widoczna. Gdyński biurowiec wykazuje także zaskakujące analogie do zaprojektowanego w 1959 r. przez Hermana Hertzbergera budynku domu studenckiego przy Weesperstraat w Amsterdamie (1966), podobieństwo widać w strukturze i rozwiązaniu przyziemia. Baltic Business Center wpisuje się stylistycznie w dorobek Dumenčicia (por. np. wieżowiec Ilmet w Warszawie, 1997), który tworzy monumentalną, hybrydyczną architekturę, korzeniami sięgającą modernistycznych wzorców, ale tkwiącą już w okresie postmodernizmu.

Biurowiec Asseco Prokom (ul. Podolska 21, inwestor: Invest Komfort ${ }^{27}$ / Prokom Investments, projekt: Miljenko Dumenčić, Stanisław Dopierała, Ryszard Girtler, Tomasz Janiszewski, 2004) liczy dziewięć kondygnacji nadziemnych oraz dwie podziemne (il. 3). W jego strukturze wyróżnić można dwa skrzydła biurowe (o rzucie zbliżonym do prostokąta) połączone łącznikiem oraz przeszklonym atrium o przekroju trapezu. Budynek cechują wysokiej jakości materiały wykończeniowe: okładzina $\mathrm{z}$ naturalnego kamienia (trawertynu i granitu, stosowanych często w przyziemiach modernistycznych kamienic), białe szkło i elementy stalowe. Do południowego skrzydła przylega charakterystyczny przeszklony półwalec - przestrzenna dominanta, o powierzchni ukształtowanej z wąskich, pionowych, nachodzących na siebie tafli. Daleką inspiracją mogła tu być bryła Domu Żeglarza Polskiego (projekt: Bohdan Damięcki, Tadeusz Sieczkowski, 1937) lub Akwarium Gdyńskiego (projekt: Leonard Tomaszewski, Juliusz Żakowski, 1939) ${ }^{28}$. Z kolei tylna elewacja budynku może nasuwać skojarzenia z gdyńską architekturą industrialną, np. łuszczarnią ryżu (projekt: Kazimierz Krzyżanowski, 1928). Przyczyniają się do tego dobór kolorów, surowy charakter elewacji i sama bryła budynku, która od strony wschodniej wygląda masywnie.

Po przeciwnej stronie torowiska znajduje się Alfa Plaza Business Center (ul. Stefana Batorego 28-32, inwestor: Grupa JWK, projekt: Firma Architektoniczna Horus - Piotr Rutkowski, 2000). Budynek ma osiem kondygnacji nadziemnych (z czego dwie najwyższe wycofane) oraz dwie podziemne i składa się z czterech segmentów zgrupowanych wokół wewnętrznego atrium (il. 4). Południowe „skrzydło” budynku zwęża się dynamicznie i występuje przed lico wschodniej elewacji w formie przeszklonego, zaokrąglonego narożnika.

27 W 2000 r. deweloper (Invest Komfort) zrealizował budynek w stanie surowym, http:// www.investkomfort.pl/zrealizowane_inwestycje/Gdynia,1/Biurowiec,20 [dostęp: 14.04.2014].

28 Charakterystyczna szklana rotunda Akwarium Gdyńskiego została dobudowana już po wojnie, zob. http://modernizmgdyni.pl/?p=297 [dostęp: 14.04.2014]. 


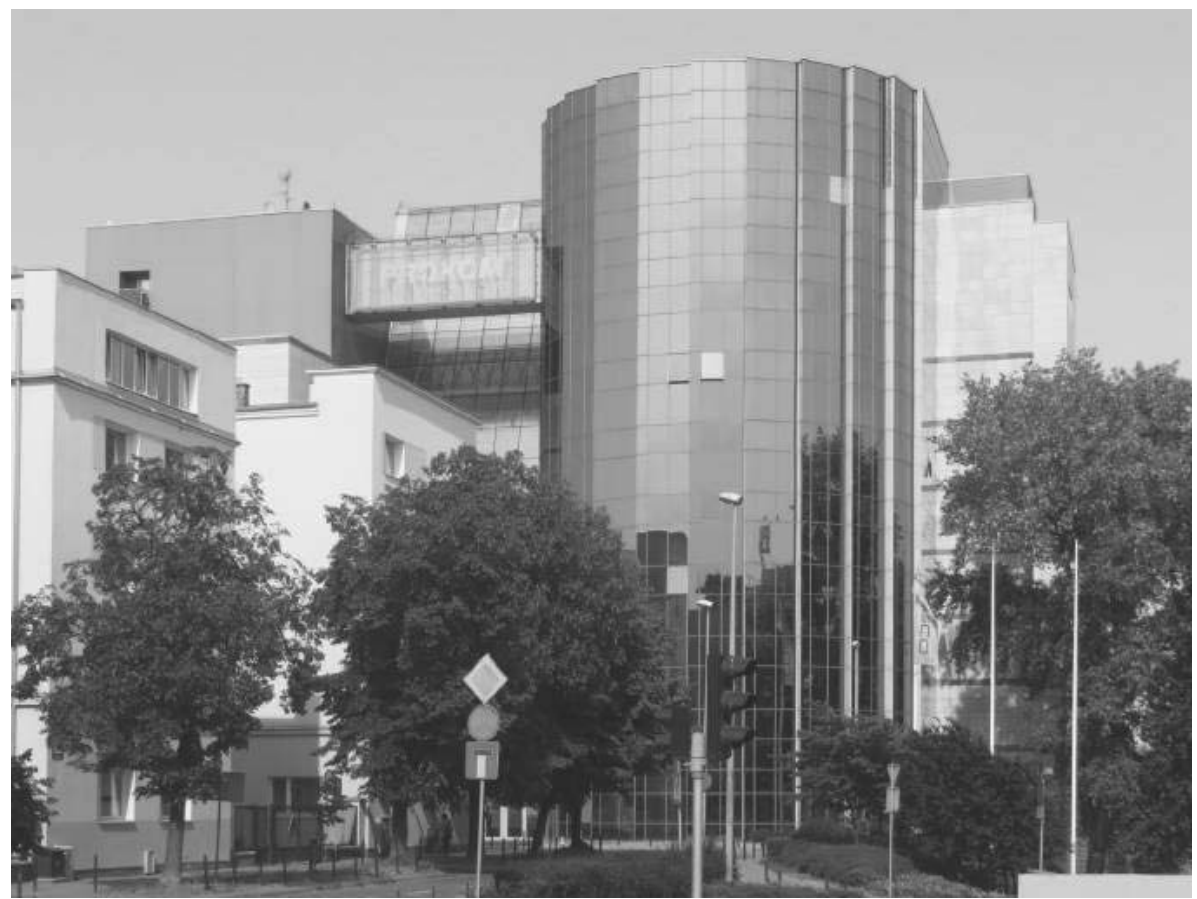

Architektura

w śródmieściu

Gdyni...

Il. 3. Gdynia, biurowiec Asseco Prokom, ul. Podolska 21, projekt: Miljenko Dumenčic, Stanisław Dopierała, Ryszard Girlter, Tomasz Janiszewski, 2004, fot. Irina Gavrash

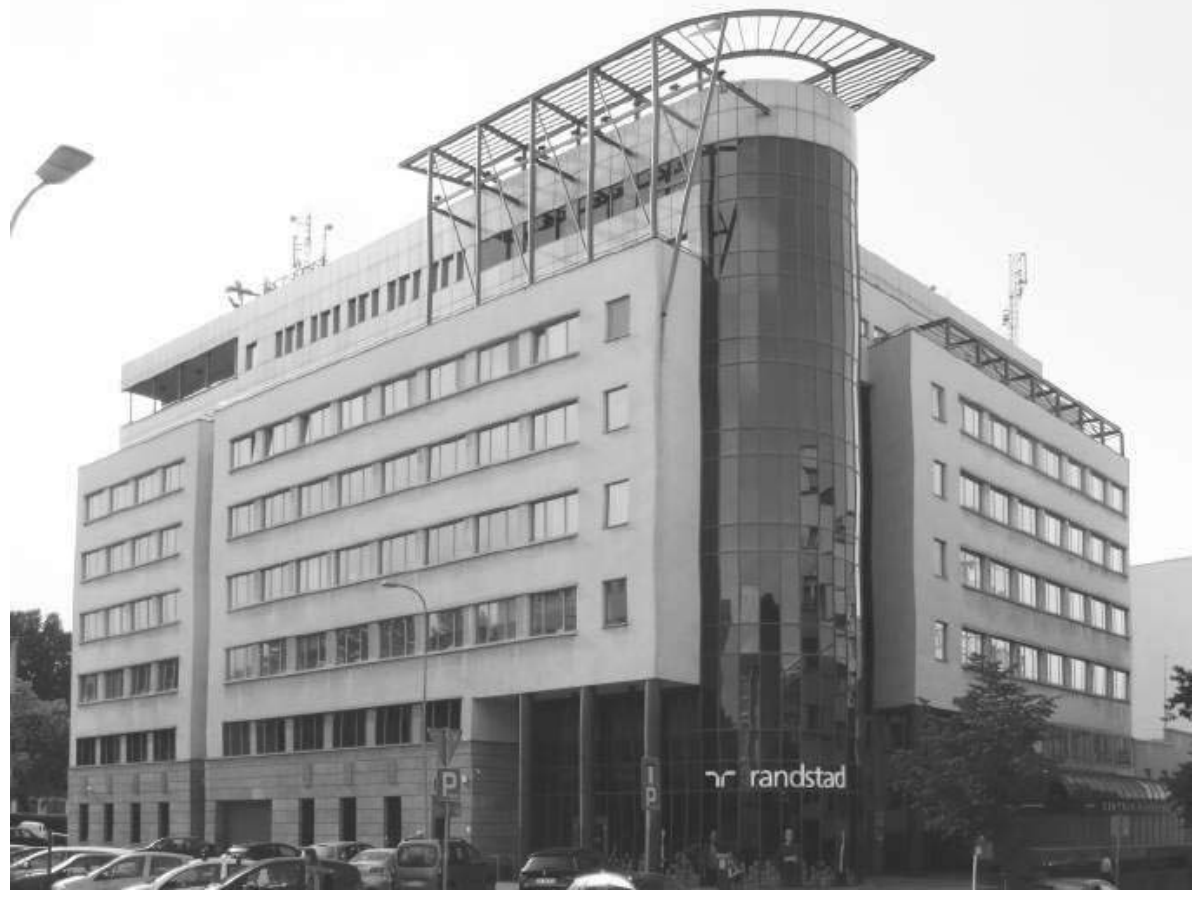

Il. 4. Gdynia, Alfa Plaza Business Center, ul. Stefana Batorego 28-32, projekt: Piotr Rutkowski, 2000 , fot. Irina Gavrash 
Alicja Melzacka

Ze względu na lokalizację budynku starano się nadać mu formę oscylującą pomiędzy „nowoczesną" architekturą „dzielnicy biznesu” a historyczną zabudową mieszkaniową śródmieścia. Jego forma jest więc wariacją na temat narożnej kamienicy w powiększonej skali. Górne kondygnacje zostały cofnięte, a przyziemie wyodrębniono podcieniem i kamienną okładziną. W elewacji południowej zastosowano wysokie na sześć kondygnacji, wąskie przeszklenie, przypominające okno w typie "termometru” o modernistycznym rodowodzie ${ }^{29}$. Powtórzono również układ skrzydeł i opływową formę narożnika, które zastosowano wcześniej m.in. w budynku ZUS-u (projekt: Roman Piotrowski, 1936, il. 5). Dzięki wprowadzeniu asymetrii do fasady uzyskano efekt przypominający nieco styl dynamicznego funkcjonalizmu Mendelsohna. Jasna kolorystyka również nawiązuje do międzywojennych realizacji. Z kolei duża powierzchnia z refleksyjnego szkła oraz stalowe konstrukcje na poziomie tarasów i dachu należą już do współczesnych środków wyrazu.

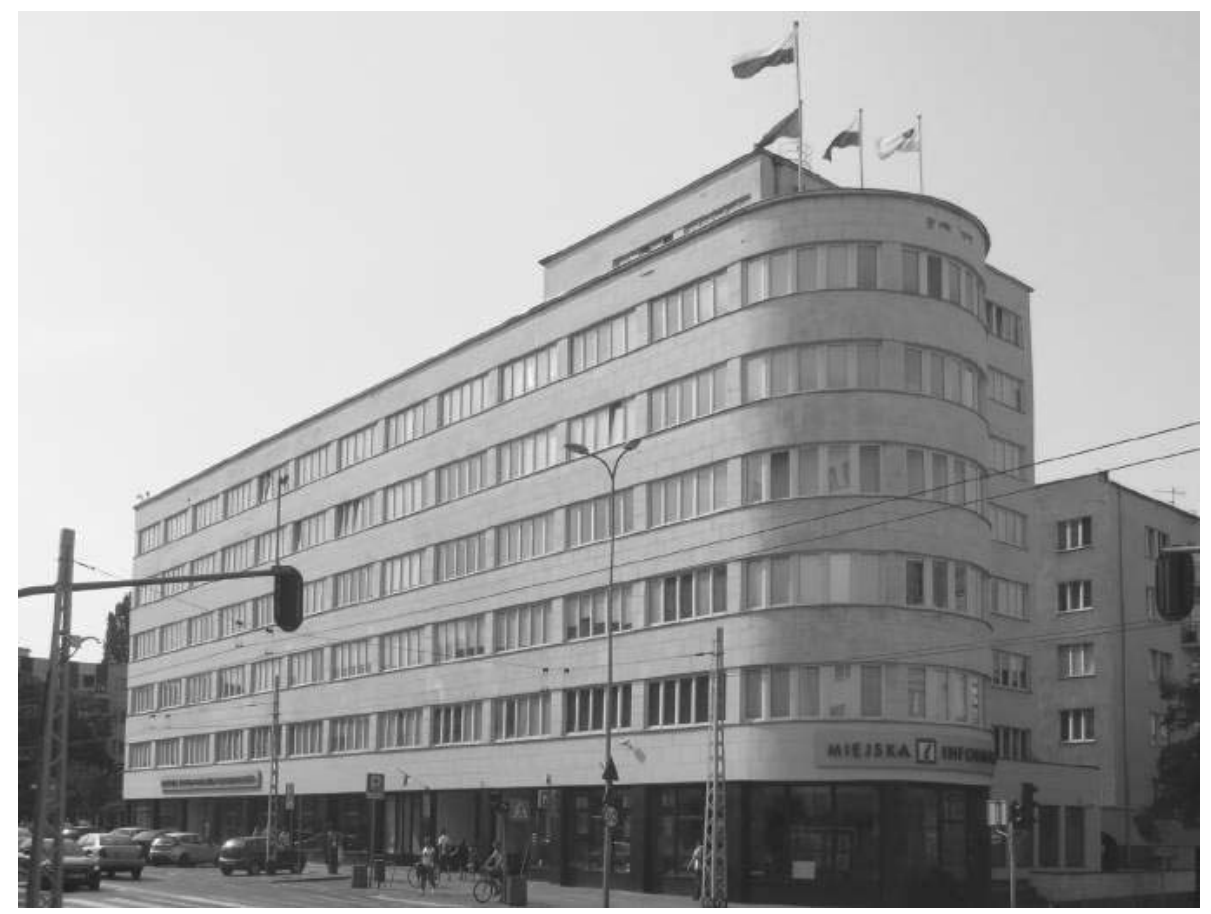

Il. 5. Gdynia, biurowiec ZUS, ul. 10 Lutego 24, projekt: Roman Piotrowski, 1936, fot. Irina Gavrash

Północna strefa śródmieścia, wyznaczona przez ulice Jana z Kolna, Portową i okolice ronda na placu Konstytucji, a od północy ograniczona terenami portowymi, jest kolejnym obszarem o niewykorzystanym potencjale urbanistycznym.

29 Por. Sołtysik, Na styku dwóch epok..., s. 185. 
Pożądane są tu zwłaszcza inwestycje prowadzące do rewitalizacji „Międzytorza" - terenów poprzemysłowych o szczególnie dużych szansach rozwojowych ${ }^{30}$. Za dobry przykład tego typu inwestycji służyć może zaadaptowanie dawnego budynku magazynowo-produkcyjnego przy ulicy św. Piotra do pełnienia funkcji $w$ śródmieściu Gdyni... hotelowych.

Hotel Blick (ul. Jana z Kolna 6, inwestor: Blick, projekt: Archidea - Marcin Sienkowski, oraz Galeonardo - Anna i Andrzej Zacharscy, 2007) ma sześć nadziemnych kondygnacji - najwyższą wycofaną, z tarasem widokowym, oraz parking podziemny (il. 6). Korpus budynku tworzą dwa prostopadłe do siebie skrzydła, z których południowe jest zakończone charakterystycznym opływowym narożnikiem. Znaczna część przyziemia fasady wykonana została ze szkła refleksyjnego. Jasne elewacje, uchodzące za element charakterystyczny dla Gdyni, urozmaicono gdzieniegdzie metalicznymi panelami. Srebrne balustrady przywodzą na myśl relingi statków. Oczywistym źródłem inspiracji dla budynku była modernistyczna

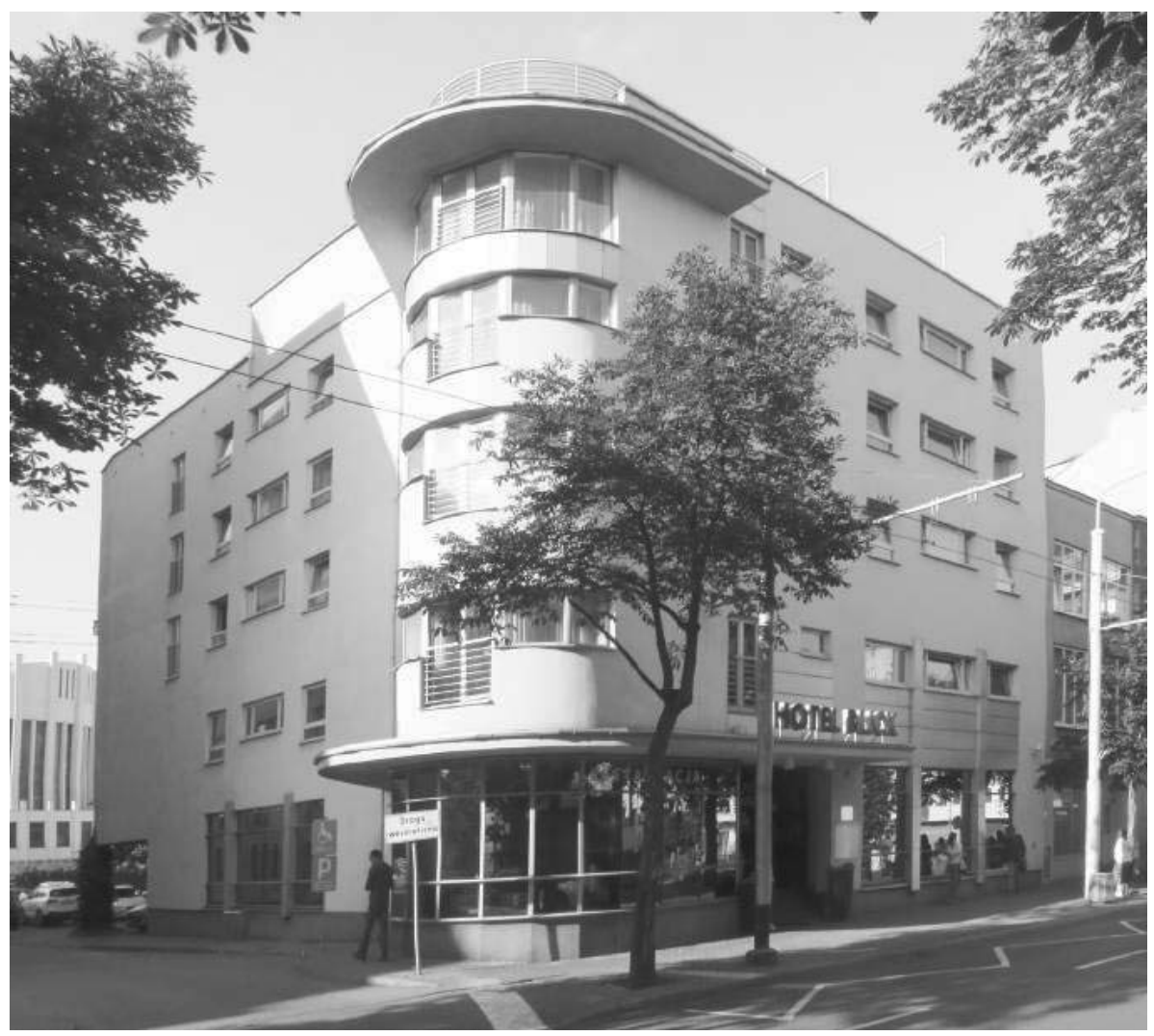

Il. 6. Gdynia, hotel Blick, ul. Jana z Kolna 6, projekt: Archidea - Marcin Sienkowski, Galeonardo - Anna i Andrzej Zacharscy, 2007, fot. Irina Gavrash

30 Por. Studium uwarunkowań i kierunków, http://www.gdynia.pl/g2/2014_01/79181_fileot. pdf [dostęp: 20.04.2014], s. 50. 
Alicja kamienica narożna. Co znamienne, hotel Blick nie jest wcale budynkiem narożMelzacka nym, ale wypełnia luźno zabudowaną pierzeję. Mimo tego postanowiono nadać mu taką właśnie formę. Forma narożnika ze specyficznym zadaszeniem została przejęta najprawdopodobniej z Domu Żeglarza Polskiego z 1937 r.

Kamienica Gdyńska (ul. św. Wojciecha 10, inwestor: Hossa, projekt: Mariusz Magda, 2005) składa się z dziewięciokondygnacyjnej bryły głównej i prostopadłych, stopniowo obniżających się skrzydeł. Budynek miał z pewnością nawiązywać do modernistycznej architektury Gdyni (il. 7). Południowo-wschodni narożnik rozczłonkowany balkonami przypomina wariację na temat wczesnego funkcjonalizmu. Natomiast południowo-zachodni, prostokątny narożnik został złagodzony przez opływową formę najwyższej kondygnacji, powtórzoną jeszcze przez wysuniętą krawędź dachu. Element ten przywodzi na myśl nadbudówkę statku. Inne „morskie” akcenty to balustrady przypominające relingi oraz okna $\mathrm{w}$ formie bulajów. W okresie międzywojennym analogiczne rozwiązanie narożnika zastosowano w kamienicy Stanisława Pręczkowskiego czy w zespole mieszkaniowym BGK. Kanonicznym przykładem opływowych form w narożniku

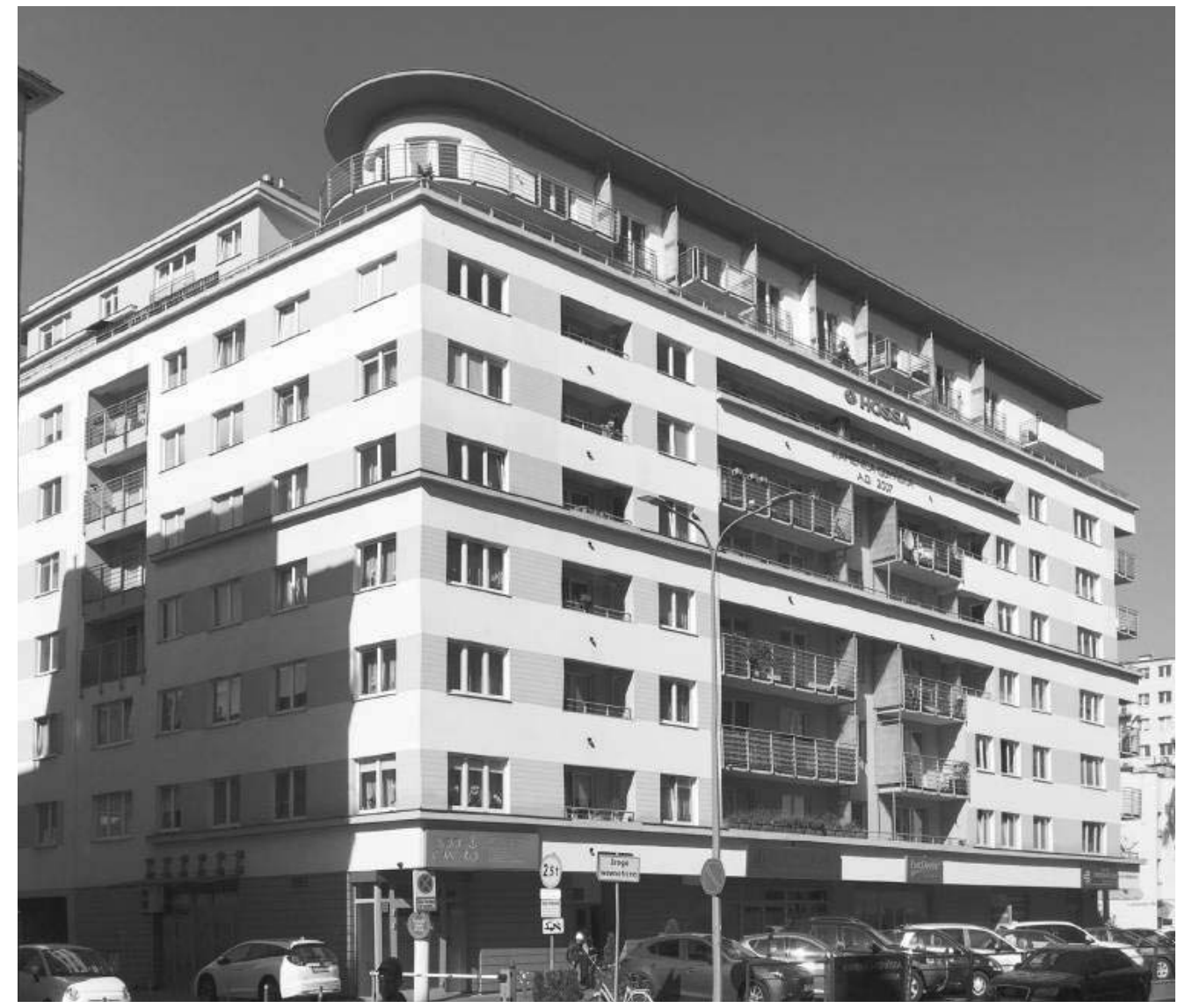

Il. 7. Gdynia, Kamienica Gdyńska, ul. św. Wojciecha 10, projekt: Mariusz Magda, 2005, fot. Szymon Jocek 
jest wrocławski Dom Handlowy Petersdorf (obecnie biurowiec Kameleon) Mendelsohna. Mniej znanym przykładem jest też budynek mieszkalny Hansa Scharouna przy Hohenzollerndamm 35-36 w Berlinie (1930).

Centralna strefa śródmieścia jest obszarem o zdecydowanie największej liczbie inwestycji, choć paradoksalnie stwarza najmniej możliwości przestrzennych. Gęsta zabudowa pierzejowa stawia architektów w sytuacji, w której głównym celem jest zagospodarowywanie pozostałej wolnej przestrzeni, tak by nie stała ona w sprzeczności z historyczną zabudową.

Kamienica Moderna (plac Kaszubski 7, inwestor: Moderna Investment, projekt: Wolski Architekci - Jarosław Rawerski, Sławomir Mydlarz, 2012) funkcjonuje jako plomba we wschodniej pierzei placu. Rozbudowana w głąb kwartału bryła ma układ schodkowy i osiąga wysokość ośmiu kondygnacji, wyłączając parking podziemny (il. 8). Tutaj również można zauważyć charakterystyczne wycofanie najwyższej kondygnacji oraz przeszklenie przyziemia, które przeznaczono na funkcje usługowe. Wydaje się, że budynek jest wariacją na temat kamienicy wewnątrzpierzejowej późnego funkcjonalizmu, a w szczególności typu z pionowym oknem „termometrem”31 (np. kamienica Antoniny Szydarkowskiej, ul. 10 Lutego 25,

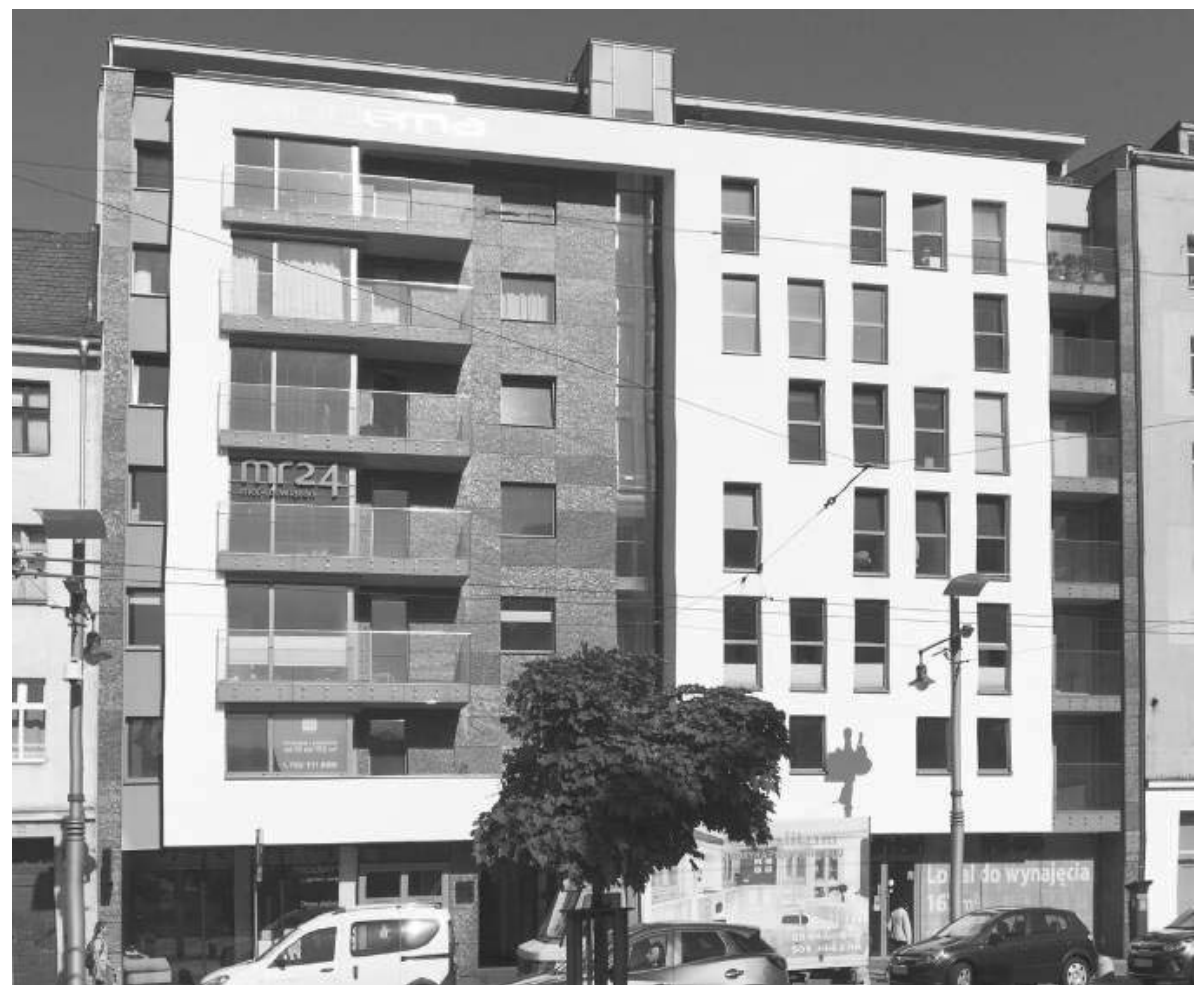

Il. 8. Gdynia, kamienica Moderna, pl. Kaszubski 7, projekt: Wolski Architekci - Jarosław Rawerski, Sławomir Mydlarz, 2012, fot. Szymon Jocek

$31 \quad$ Sołtysik, Na styku dwóch epok..., s. 198. 
Alicja projekt: Zbigniew Kupiec, Narcyz Olbrychski, 1935). Zamiast okna wprowadzono Melzacka tu panoramiczny szyb windy. Fasada jest asymetryczna - z lewej strony zastosowano nieregularny układ okien, a z prawej - „rozwarstwienie” fasady poprzez wprowadzenie tektonicznej białej ramy. Zestawienie kolorystyczne i dobór materiałów (ciemny kamień, jasny tynk) nasuwają skojarzenia ze stylistyką art déco oraz luksusowym wykończeniem (zarówno zewnętrznym, jak i wewnętrznym) kamienic $z$ lat trzydziestych.

Kamienica Invest (plac Kaszubski 15A/19, inwestor: Invest Komfort, projekt: Biuro Projektowe BJK, 2001) znajduje się na południe od Moderny, w tej samej pierzei placu (il. 9). Budynek wzniesiono na planie nieregularnej litery „T”, z oficyną środkową skierowaną w głąb kwartału. Mamy tu ponownie do czynienia z budynkiem ośmiokondygnacyjnym, wyposażonym w parking podziemny i taras, o cofniętych uskokowo dwóch najwyższych kondygnacjach i przyziemiu mieszczącym funkcje usługowe. Oceniając projekt, Sołtysik zauważa, że proponowane w fasadzie formy są „niemalże cytatem architektonicznym z gdyńskich kamienic lat trzydziestych", i stwierdza, że międzywojenna tradycja stylowa

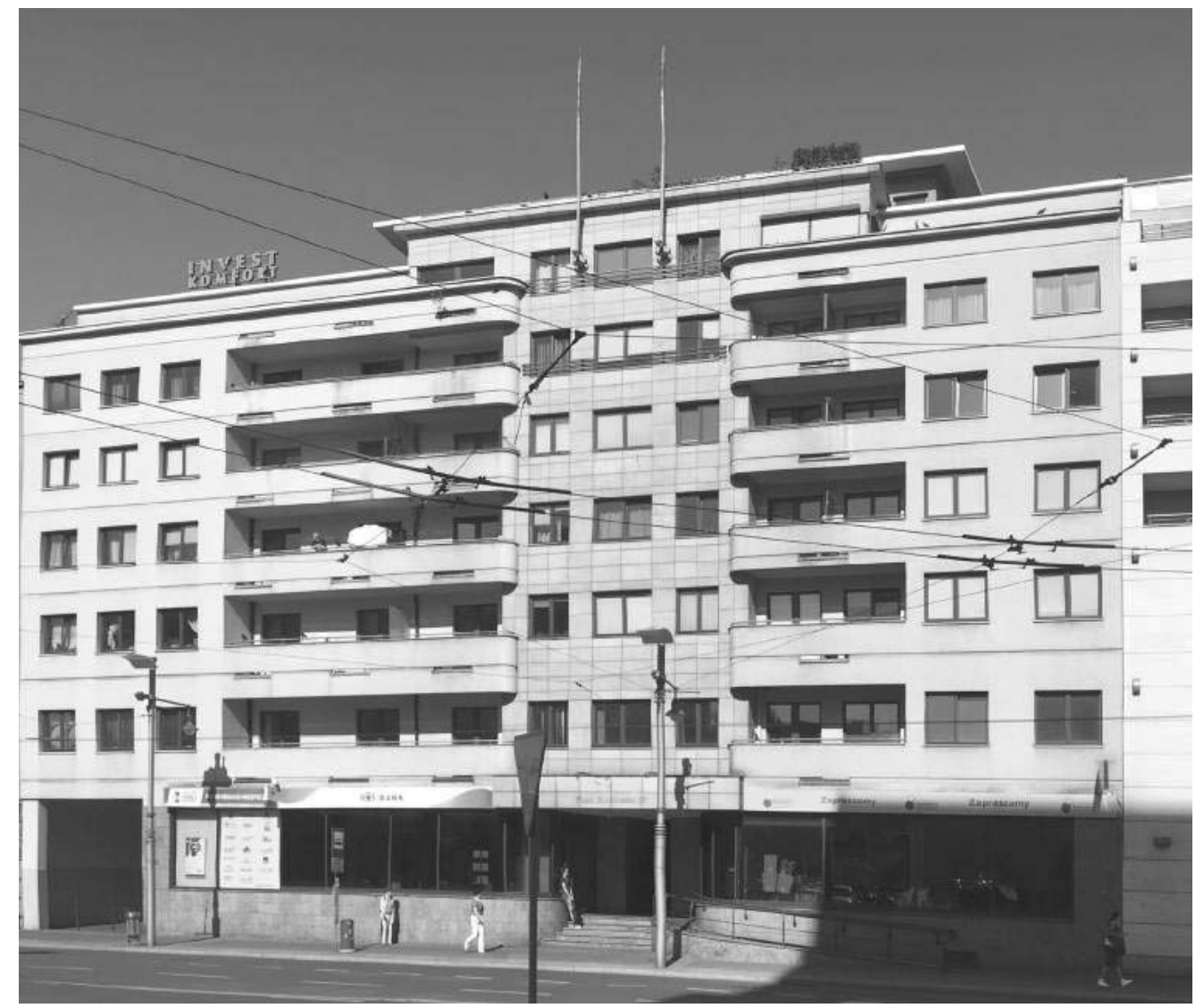

Il. 9. Gdynia, kamienica Invest, pl. Kaszubski 15A/19, projekt: Biuro Projektowe BJK, 2001, fot. Szymon Jocek 
„raczej krępowała wyobraźnię autorów, niż ją uskrzydlała”32. Trudno o trafniejszą ocenę. Część fasady została wypiętrzona, lekko cofnięta w stosunku do linii zabudowy i ujęta w rzędy nachodzących na nią balkonów o opływowych formach. Wydaje się, że ten układ kompozycyjny jest zaczerpnięty z międzywojennej kamienicy przy ulicy Świętojańskiej $87^{33}$. Od strony wewnętrznego dziedzińca budynek koliduje $\mathrm{z}$ sąsiednimi zabudowaniami, brakuje wolnej przestrzeni, co przeczy wszelkim zasadom modernistycznej urbanistyki. Choć reprezentacyjna elewacja przypomina kamienicę międzywojenną w większej skali, to jednak podobieństwo jest jedynie powierzchowne.

Transatlantyk (plac Kaszubski 19-21, inwestor: AB Inwestor Andrzej Boczek, projekt: Archi-Tech-T Pilch \& Partnerzy - Bazyli Domsta, Marcin Pilch, 2011) jest przykładem nielicznie reprezentowanej w Gdyni zabudowy wysokościowej - ma jedną kondygnację podziemną, a w najwyższym punkcie aż dwanaście nadziemnych (il. 10). Bryła budynku ma uskokową strukturę, ulega stopniowemu podwyższeniu w kierunku południowo-zachodniego narożnika, który stanowi zamknięcie osi ulicy Świętojańskiej, a zarazem dominantę architektoniczną placu Kaszubskiego. W budynku wykorzystano wiele powtarzanych już wielokrotnie rozwiązań: charakterystyczny narożnik, wyodrębnione przyziemie (poprzez przeszklenie i wprowadzenie podcienia) czy pasowy układ elewacji (co prawda, bardzo zmodyfikowany przez alternację typów okien). Wysunięcie ściany osłonowej, zastosowanie wielkopowierzchniowej, przeziernej gdzieniegdzie ściany kurtynowej, wprowadzenie ażurowego okapu i konstrukcji stalowej w partii dachu nadają budynkowi charakter pozornej konstrukcyjności i służą wzbudzeniu skojarzeń z nowoczesnością i technologią.

Najbardziej prawdopodobnym źródłem inspiracji jest tu międzywojenny budynek ZUS-u. Forma budynku oddaliła się jednak znacznie od pierwowzoru - architekt poszedł o krok dalej, rozbijając zwartą bryłę i różnicując ją przestrzennie; nadał jej tym samym znamiona dekonstruktywizmu. Transatlantyk można uznać za pewnego rodzaju dekonstrukcję form modernizmu lat trzydziestych i ich ponowne złożenie, reinterpretację.

Gdyńskie Centrum Biznesu (plac Kaszubski 8, inwestor: RB Przedsiębiorstwo Polsko-Amerykańskie, projekt: Marian i Jacek Synakiewicz, 1998) ma rzut zbliżony do prostokąta i wysokość ośmiu kondygnacji (il. 11). Próba dopasowania budynku do otaczającej go architektury zakończyła się w tym wypadku uzyskaniem bardzo „fasadowego” efektu. Reprezentacyjne elewacje imitować mają narożną kamienicę. Wykazują one podobieństwo do kamienicy Hundsdorffów (projekt: Marian Maśliński, 1933) oraz berlińskiego Mossehaus (projekt: Erich Mendelsohn, 1923). Wystarczy jednak spojrzeć na rzut budynku oraz tylną elewację, by zauważyć, że przypomina on bardziej współczesny blok mieszkalny. Czytelną formę

32 Archiwum UM Gdyni, Opinia Komisji Urbanistyczno-Architektonicznej przy Zarządzie Miasta Gdyni o projekcie koncepcyjnym budynku mieszkalno-usługowego przy placu Kaszubskim 13A/15 [...], 1999, teczka nr 37/15.

33 Na tę zależność zwróciła uwagę Sołtysik, Inspiracje międzywojenne..., s. 53. Gdyni... 


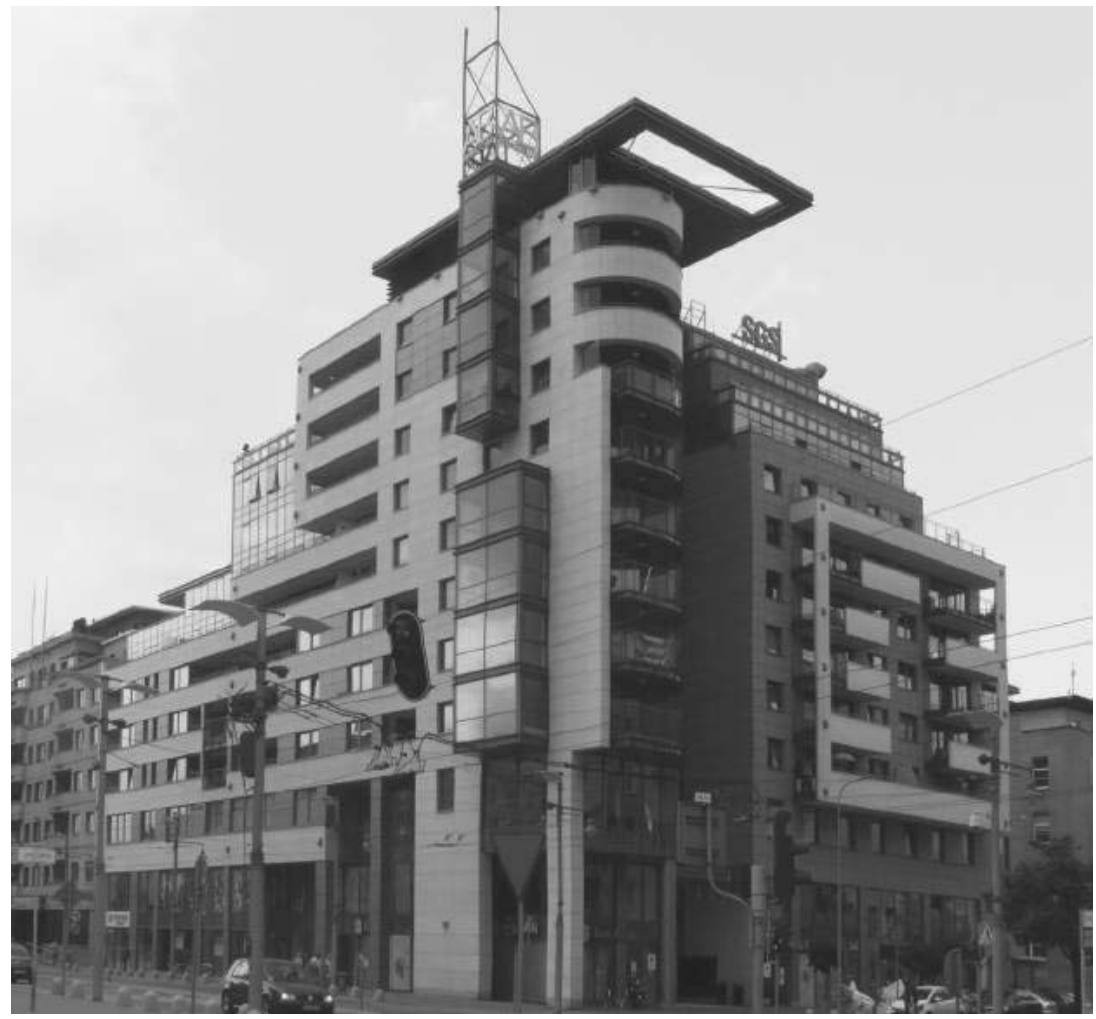

Il. 10. Gdynia, Transatlantyk, pl. Kaszubski 19-21, projekt: Archi-Tech-T Pilch \& Partnerzy - Bazyli Domsta, Marcin Pilch, 2011, fot. Irina Gavrash

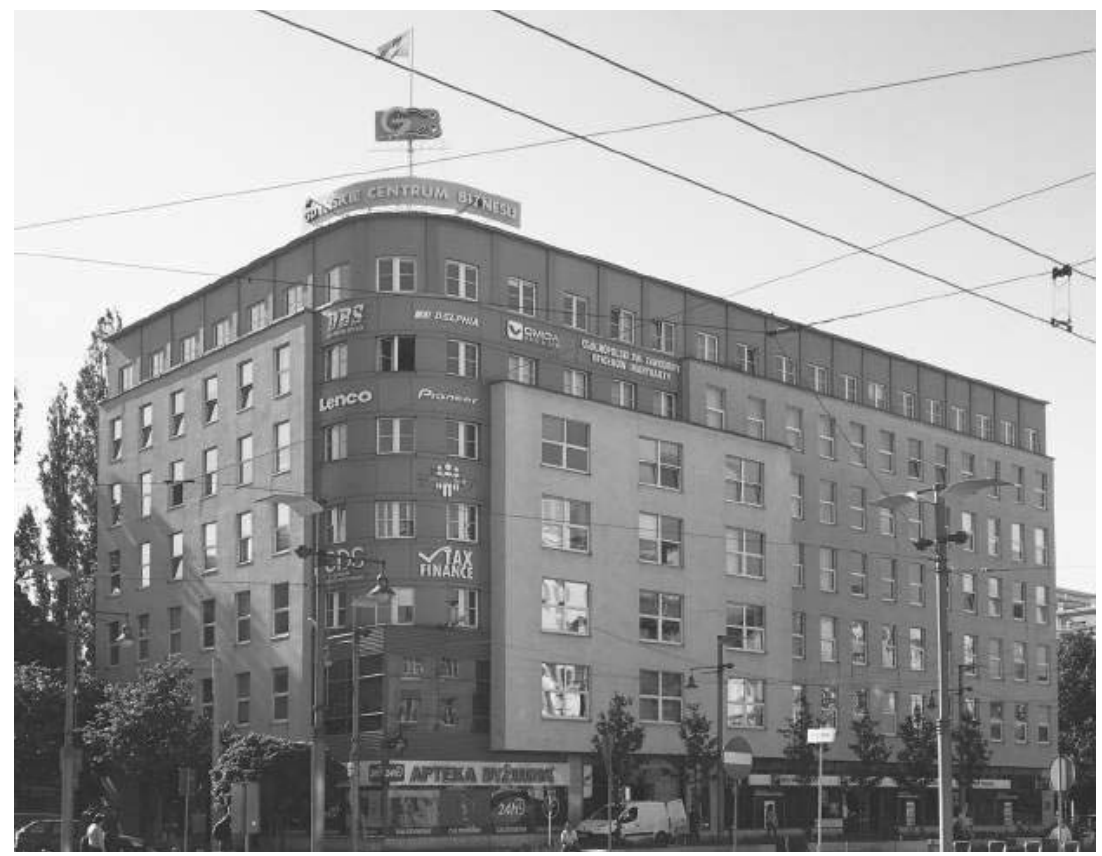

Il. 11. Gdynia, Gdyńskie Centrum Biznesu, pl. Kaszubski 8, projekt: Marian i Jacek Synakiewicz, 1998, fot. Szymon Jocek 
bryły zatarło zastosowanie różnego rodzaju materiałów elewacyjnych: okładziny kamiennej, tynku, szkła i aluminium, mających nadać mu współczesny charakter. Podobne zabiegi, doprowadzone jednak do skrajności, występują w znanym postmodernistycznym projekcie Jamesa Stirlinga - no. 1 Poultry w londyńskim City (1997). Podobne ukształtowanie narożnika oraz „warstwowych" ścian osłonowych świadczy o tym, że gdyńska realizacja również nosi znamiona postmodernizmu.

InfoBox - Obserwatorium Zmian (ul. Świętojańska 30, projekt: Jacek Droszcz, 2010) poprzez swoją pomysłową i prostą formę doskonale wpisuje się w obszar Skweru Żeromskiego (il. 12) ${ }^{34}$. Realizacja gdyńska odgrywa prócz tego ważną rolę w integrowaniu lokalnej społeczności - mieści się tam przestrzeń warsztatowa, rekreacyjna i gastronomiczna. Gdyński InfoBox stanowi zabudowę tymczasową, o łatwej do zmodyfikowania strukturze modułowej. Składa się z 65 kontenerów, częściowo przeszklonych, tworzących na placu rozciągniętą, horyzontalną kompozycję. Wieża wi-

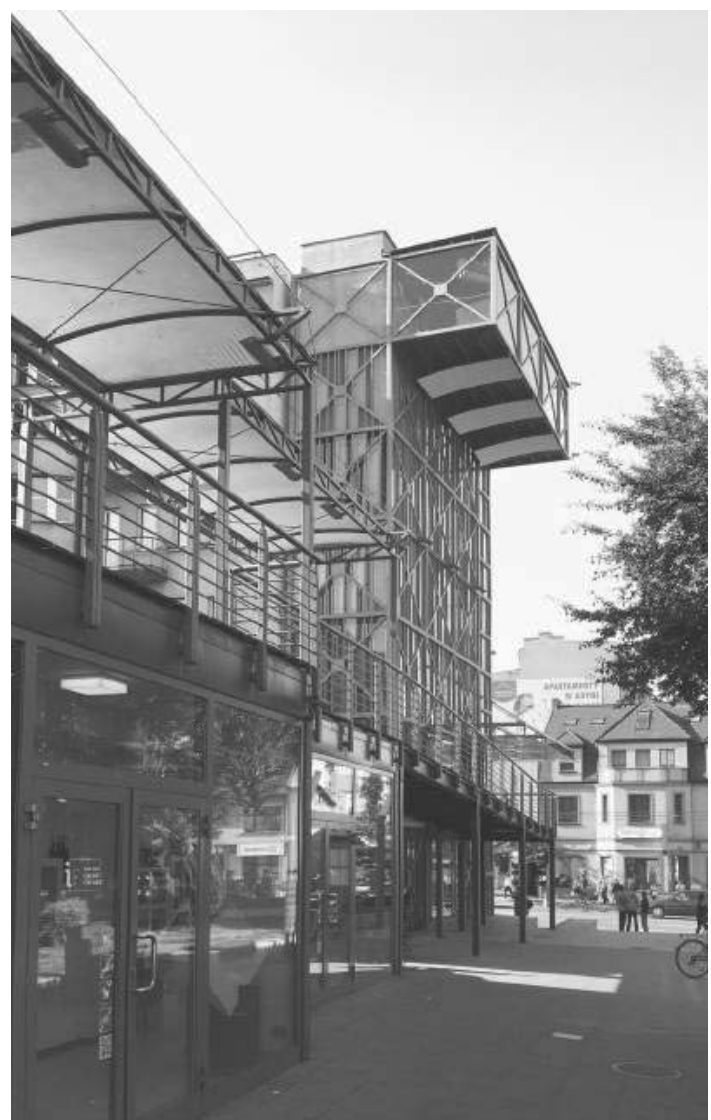

Il. 12. Gdynia, InfoBox - Obserwatorium Zmian, ul. Świętojańska 30, projekt: Jacek Droszcz, 2010, fot. Szymon Jocek dokowa - Panoramium - o wysokości siedmiu kondygnacji, zamyka ciąg od północnego wschodu. Budynek dowodzi tego, że użycie kontenerów, a więc prefabrykatów, do tworzenia architektury nie musi wcale ograniczać inwencji architekta. InfoBox jest projektem, który przyczynił się do rewitalizacji bardzo ważnej przestrzeni publicznej.

Centrum Handlowe Batory (ul. 10 Lutego 11, inwestor: Kupcy Gdyńscy SA, projekt: Warsztat Architektury - Krzysztof Kozłowski, 1999) ma nieregularny rzut, w uproszczeniu przypominający prostokąt, a jego wysokość waha się od trzech do siedmiu kondygnacji (il. 13). Budynek podzielić można na trzy części: zasadniczy korpus, przeszklone atrium (pełniące funkcję łącznika) oraz soczewkowatą bryłę. Jej charakterystyczny, ostro zakończony narożnik wychodzący na skrzyżowanie ulic Władysława IV i 10 Lutego przywodzi na myśl dziób statku. Najwyższa

34 Koncepcja infoboxu jako centrum informacji o miejskich inwestycjach pochodzi z Zachodu, zob. www.gdyniainfobox.pl/info-box/otwarcie-infoboxu/swiatowy-tren/ [dostęp: 12.03.2014]. 


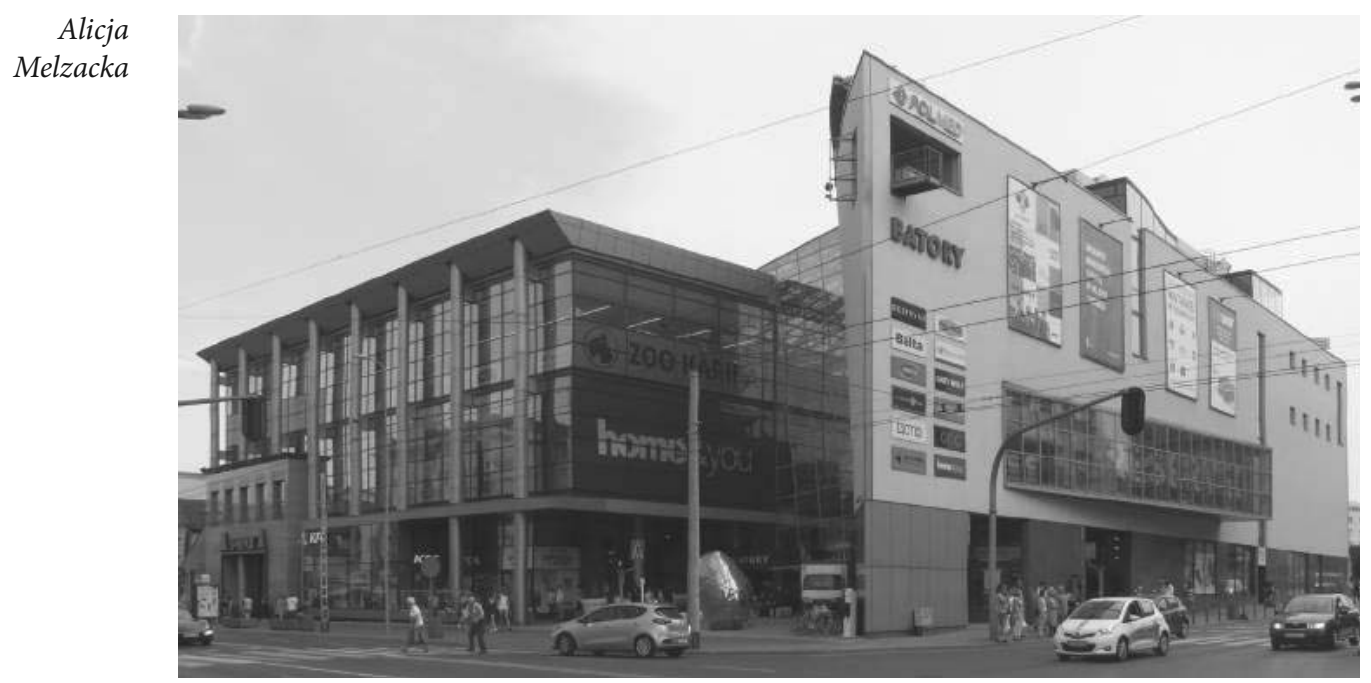

Il. 13. Gdynia, Centrum Handlowe Batory, ul. 10 Lutego 11, projekt: Warsztat Architektury Krzysztof Kozłowski, 1999, fot. Irina Gavrash

kondygnacja o mniejszym obrysie oraz przeszklone szyby wind imitują nadbudówki statku. Zastosowanie technologii ściany kurtynowej oraz elementów z blachy i tworzyw sztucznych stanowiło próbę stworzenia rodzimej architektury high-tech, niestety skonfrontowaną z realiami ekonomicznymi swoich czasów. C.H. Batory ma pełnić rolę budynku-znaku, wskazującego na dążenie do nowoczesności przy równoczesnym kultywowaniu pamięci o tożsamości morskiej Gdyni. Jednak nie tyle korzysta on z repertuaru środków tzw. stylu okrętowego, ile imituje bryłę statku. Tak dosłowne nawiązanie do kształtu okrętu nie jest w Polsce ewenementem. Realizacje oparte na podobnej koncepcji architektury figuratywnej, choć często o zupełnie odmiennej formie, można spotkać m.in. w Poznaniu (Jet Office, projekt: Pracownia Architektoniczna Insomia, 2012) czy Warszawie (Batory Office, projekt: E\&L Architects, 2009). Mimo że tego typu rozwiązania utożsamiane są z postmodernizmem, to już w latach trzydziestych XX w. amerykańscy architekci osiągnęli podobny efekt, projektując muzeum żeglugi w San Francisco - sztandarowy przykład Streamline Moderne.

Centrum Handlowe Kwiatkowskiego (ul. 10 Lutego 16, inwestor: Versus Investments, projekt: SAP Projekt Północ - Mirosław Hrynkiewicz, Marek Kleczkowski, Małgorzata Opioła-Kozłowska, 2004) ma sześć kondygnacji nadziemnych i dwie podziemne (il. 14). Jego trójskrzydłowy układ powtarza rozwiązania znane z pobliskiego międzywojennego gmachu Poczty Głównej (projekt: Julian Puterman-Sadłowski, Antoni Miszewski, 1929) ${ }^{35}$. Fascynacja maszynową estetyką przejawia się $\mathrm{w}$ architekturze centrum przede wszystkim poprzez zastosowanie okładziny z blachy oraz dużej, przeziernej ściany kurty-

35 Sołtysik, Inspiracje międzywojenne..., s. 50. 


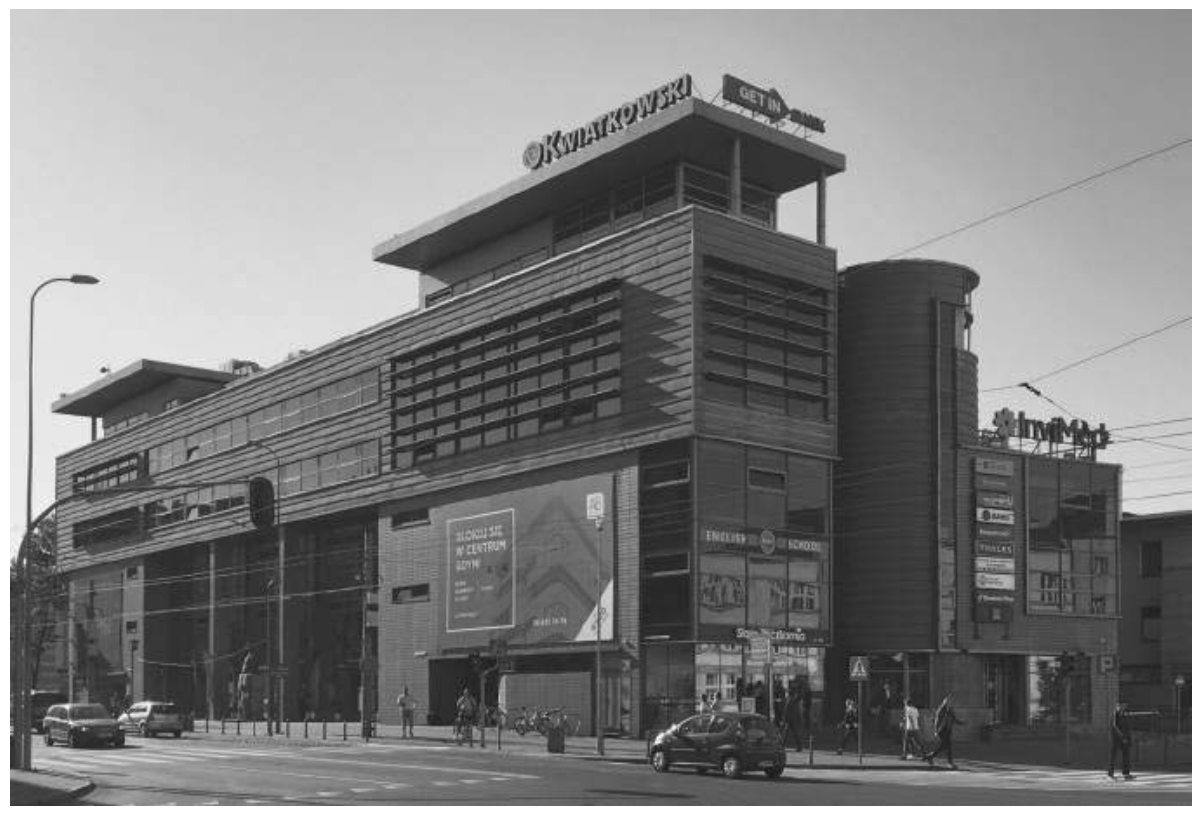

Architektura w śródmieściu Gdyni...

Il. 14. Gdynia, Centrum Handlowe Kwiatkowskiego, ul. 10 Lutego 16, projekt: SAP Projekt Północ - Mirosław Hrynkiewicz, Marek Kleczkowski, Małgorzata Opioła-Kozłowska, 2004, fot. Szymon Jocek

nowej, umożliwiającej wgląd we wnętrze budynku z systemem ciągów komunikacyjnych i elementów nośnych. Zastosowanie surowych materiałów oraz prostych form kojarzyć się może z minimalistyczną architekturą Ludwiga Miesa van der Rohe. Charakterystyczna fasada centrum, flankowana dwoma „pylonami" o pulpitowych dachach, wykazuje pewne podobieństwo do Wrightowskiego Hotelu Park Inn w Mason City (1910) czy Musterfabrik Waltera Gropiusa i Adolfa Meyera (1914).

Nadmorska Strefa Prestiżu obejmuje obszar na styku miasta z morzem (od Pirsu Dalmorowskiego po Bulwar Nadmorski) i stanowi współczesną kontynuację międzywojennej koncepcji tzw. Dzielnicy Reprezentacyjnej. Jest to obszar planowanych ważnych inwestycji, takich jak Forum Kultury czy Gdynia Waterfront.

Centrum Kultury i Rozrywki Gemini (obecnie Gdynia Waterfront, ul. Waszyngtona 21, inwestor: Portico Development, projekt: HOK International - Paul Ayre, 2001) składa się z pary prostopadłych względem siebie skrzydeł o wysokości dwóch kondygnacji (il. 15). W miejscu ich styku znajduje się patio na planie owalu, które z zewnątrz imituje rotundę. Ściany od strony parkingu i zaplecza są niemal ślepe, natomiast elewacje reprezentacyjne przepruto oknami, a w przyziemiu - witrynami. Wykończenie budynku jest równie oszczędne - zastosowano biały i szary tynk oraz metaliczną okładzinę. Wydaje się, że Centrum Gemini jest hybrydą zachodniego purystycznego modernizmu i surowej architektury 


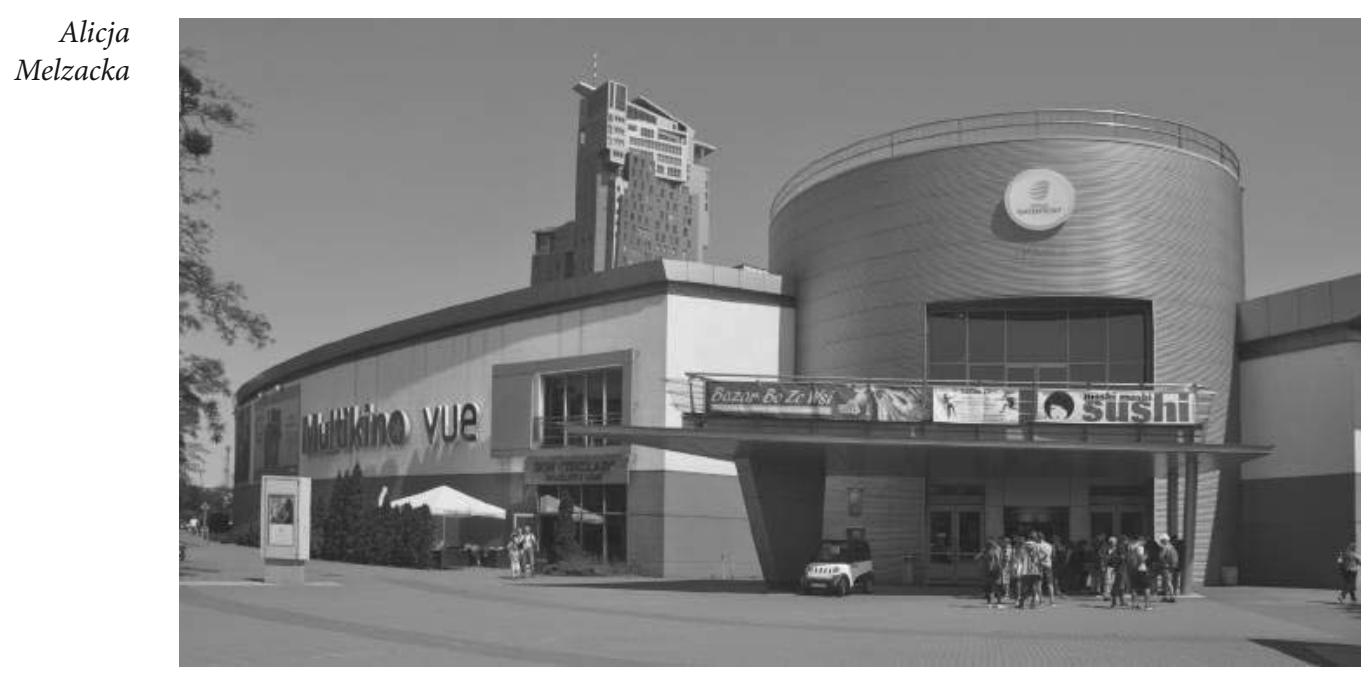

Il. 15. Gdynia, Centrum Kultury i Rozrywki Gemini, ob. Gdynia Waterfront,

ul. Waszyngtona 21, projekt: HOK International - Paul Ayre, 2001, fot. Marta Borowska

przemysłowej. Metaliczna „rotunda”, nawiązująca do estetyki maszyny, ma nadawać budynkowi nowoczesny charakter. Być może korespondować miała z rotundą znajdującego się również przy Skwerze Kościuszki Akwarium Gdyńskiego. Elementami odwołującymi się do „rodzimej” estetyki, mającymi umieścić budynek w kontekście nadmorskiego miasta, są wszelkie opływowe, łukowate formy oraz bulaje i relingi. Centrum wraz z przylegającym parkingiem zajmuje duży obszar, nie wykorzystując jednak w pełni jego potencjału. Ekonomia budowania „w górę” i względy estetyczne mogą wkrótce położyć kres jego istnieniu.

Sea Towers (ul. Hryniewickiego 6, inwestor: Invest Komfort, projekt: Andrzej Kapuścik, 2009) uchodzi za najważniejszą inwestycję budowlaną ostatnich lat i bez wątpienia stanowi jedną z najistotniejszych dominant architektonicznych na obszarze historycznego układu urbanistycznego śródmieścia Gdyni (il. 16). Budynek łączy w sobie typowy schemat dwóch wież o wspólnej podstawie z elementami o rodowodzie dekonstruktywistycznym. Wieże różnią się nie tylko wysokością (36 i 28 kondygnacji), lecz także przekrojem, który w obu wypadkach jest asymetryczny. Warstwowo kształtowana elewacja, a zwłaszcza jej partie o krzywolinijnym profilu, dynamizują budynek, rozbijają zwartą bryłę, która sprawia wrażenie rozpadania się pod wpływem działania sił wewnętrznych. $Z$ drugiej strony elewacja, przypominająca miejscami grubą „obudowę”, może wywoływać skojarzenia z postmodernizmem, tak jak zresztą inne realizacje Kapuścika, w których widać zamiłowanie do warstwowego, dekoracyjnego zestawiania materiałów (np. w Banku Handlowym w Katowicach, 1995). W przypadku Sea Towers zrezygnowano z tak kontrastowych połączeń, dzięki czemu osiągnięto stosunkowo surowy efekt, pasujący do poprzemysłowego krajobrazu Molo Rybackiego. Sea Towers okazało się jednak projektem kontrowersyjnym, krytykowano nie tylko 
jego formę i lokalizację, lecz także elitarny charakter.

Budynek mieszczący Muzeum Miasta Gdyni i Muzeum Marynarki Wojennej (ul. Zawiszy Czarnego 1, inwestor: Gmina Gdynia / Marynarka Wojenna RP, projekt: Warsztat Architektury - Krzysztof Kozłowski, 2007) wzniesiony przy Bulwarze Nadmorskim, składa się z dwóch połączonych brył na rzucie trapezu o wysokości od czterech do pięciu kondygnacji (il. 17). W skład kompleksu wchodzą również ekspozycja plenerowa Muzeum Marynarki Wojennej oraz zabytkowa Polska Riwiera (kiedyś hotel, obecnie Klub Marynarki Wojennej Riwiera), z którym budynek tworzy zamkniętą całość okalającą wewnętrzne podwórze. Projektanci musieli stworzyć formę o oryginalnej architekturze, nieprzytłaczającej jednak sąsiadującego zabytku. Zamiast przejąć klasycyzujący podział elewacji $z$ historycznego budynku Riwiery, gmach Muzeum proponuje ciągłą, jednolitą płaszczyznę elewacji. Zdecydowano się na natu-

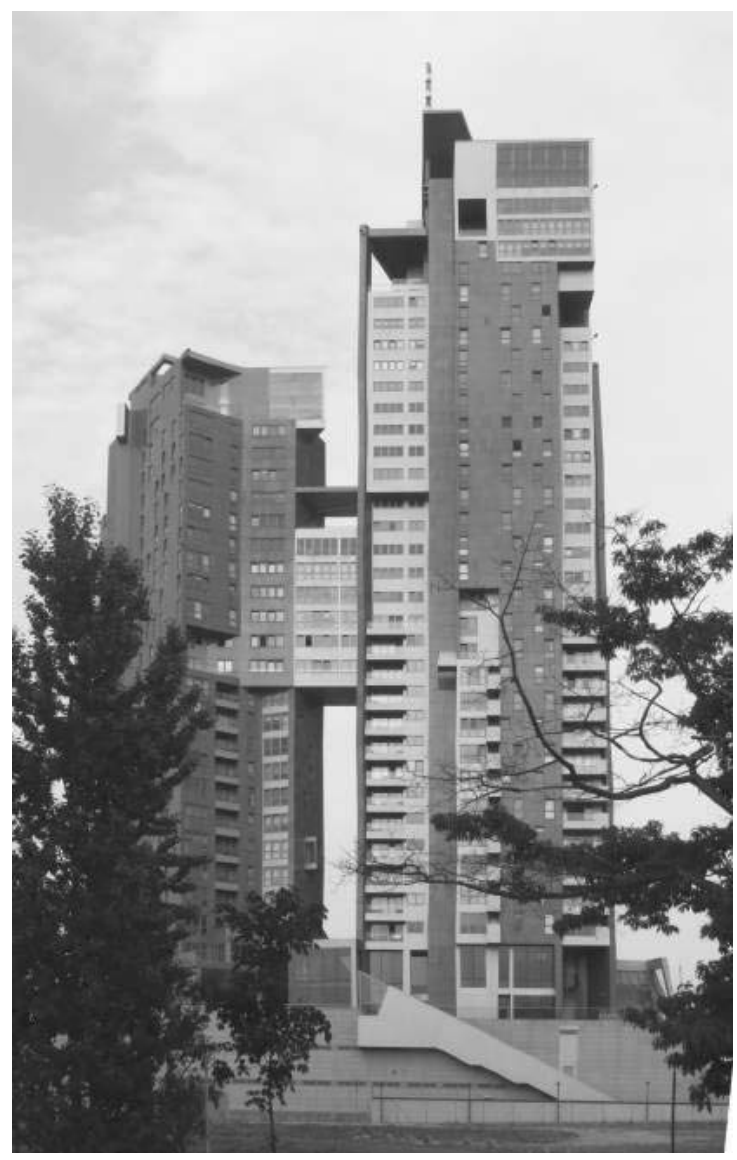

Il. 16. Gdynia, Sea Towers, ul. Hryniewickiego 6, projekt: Andrzej Kapuścik, 2009, fot. Irina Gavrash ralną okładzinę w odcieniu „ciepłe-

go piasku", typową dla gdyńskich kamienic. Nowy budynek o sporych gabarytach i prostej formie dobrze wpisał się w przestrzeń - nie jako dominanta, ale dopełnienie krajobrazu. Od strony fasady Muzeum Miasta widoczna jest charakterystyczna, odchodząca od głównego korpusu, soczewkowata bryła, której jedyną analogią pod względem skali i formy jest skrzydło gmachu gdyńskiego Sądu Rejonowego. Z kolei fasada Muzeum Marynarki Wojennej może budzić skojarzenia $\mathrm{z}$ formą okrętu.

Wyraz architektoniczny omawianego budynku zbliża go do współczesnych obiektów muzealnych o purystycznym, a zarazem monumentalnym charakterze, które Diane Ghirardo nazywa muzeami-sanktuariami ${ }^{36}$, np. do realizacji Alvaro Sizy. Ghirardo uważa, że podąża on „nurtem architektury głęboko wrażliwej wobec swojego otoczenia, jednak bez poddawania się wybuchom nostalgii lub

36 Diane Ghirardo, Architektura po modernizmie, Toruń 1999, s. 73-77. 


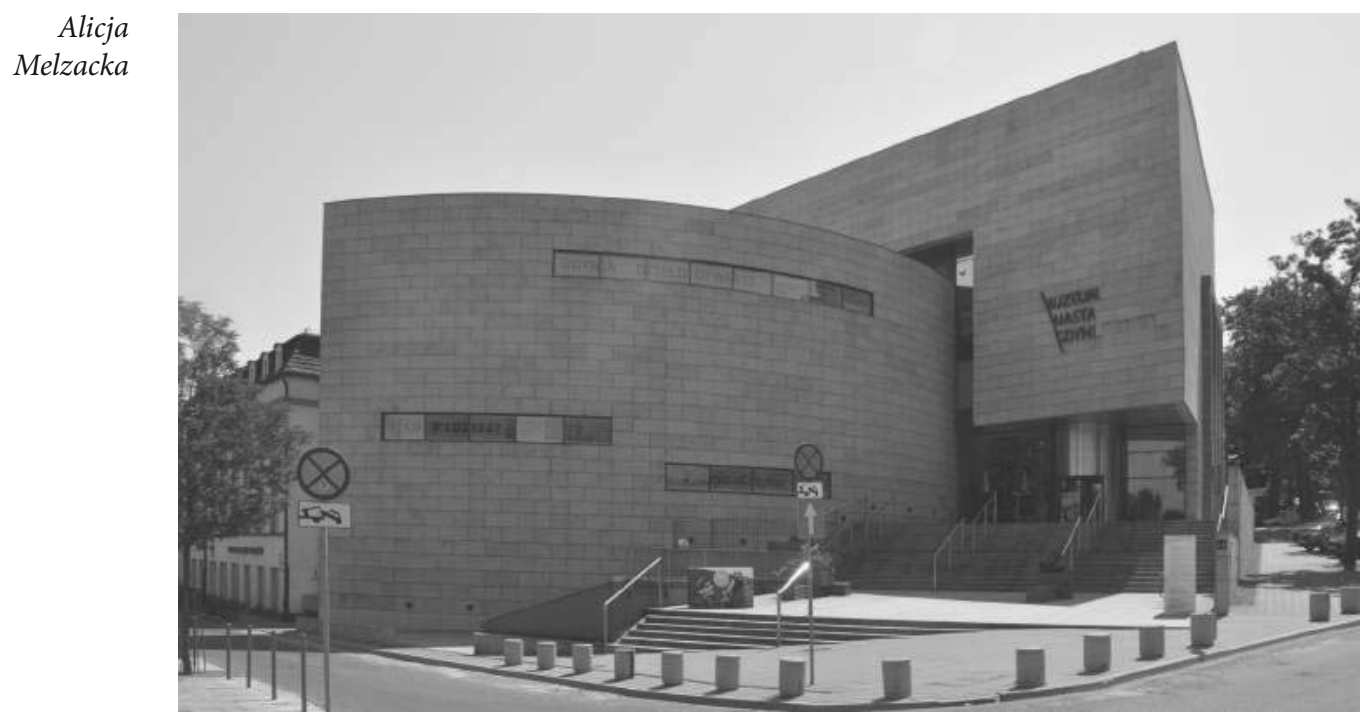

Il. 17. Gdynia, Muzeum Miasta Gdyni i Muzeum Marynarki Wojennej, ul. Zawiszy Czarnego 1, projekt: Warsztat Architektury - Krzysztof Kozłowski, 2009, fot. Marta Borowska

naiwnego kontekstualizmu"37. Sądzę, że słowa te trafnie charakteryzują również gdyński budynek muzealny.

Współczesną architekturę Gdyni umieścić można w nurcie szeroko pojętego kontekstualizmu. Wyróżniłam trzy przenikające się tendencje architektoniczne, z których każda w jakiś sposób reaguje na kontekst miejsca. Nie mają one charakteru określeń stylowych, ale wyrażają płynne trendy w architekturze, przejawiające się w różnych realizacjach, w odmiennym stopniu i często niemożliwe do rozdzielenia. Są to tendencje: regionalizująca - czerpiąca z repertuaru form architektury międzywojennej, semiotyczna - operująca niejednokrotnie dosłownymi znakami (ikonami) ${ }^{38}$, oraz technologizująca, którą można postrzegać jako ideologiczną kontynuację modernistycznego imperatywu nowoczesności.

Odniesienia regionalne i historyczne powróciły do architektury w latach sześćdziesiątych wraz z postmodernizmem ${ }^{39}$, który do Polski dotarł na przełomie lat osiemdziesiątych i dziewięćdziesiątych XX w. i, paradoksalnie, objawił się w gdyńskiej architekturze poprzez nawiązania do form modernizmu

37 Ibidem, s. 76.

38 Aby dokładniej oddać charakter relacji między formami architektonicznymi a ich przesłaniem, powinnam raczej zastosować określenie architektura ikoniczna, gdzie znak ikoniczny jest powiązany z elementem oznaczanym poprzez podobieństwo. Szerzej na ten temat w końcowej partii niniejszego artykułu.

39 Por. Charles Jencks, Narodziny architektury postmodernistycznej [w:] Teorie i manifesty architektury wspótczesnej, red. Charles Jencks, Karl Kropf, Warszawa 2013; Józef Tarnowski, Transformacje estetyczne architektury i urbanistyki w XX wieku, „Estetyka i Krytyka” 2002, nr 2(3), s. 85-106; Piotr Piotrowski, W kręu dyskusji postmodernistycznych, „Artium Quaestiones” 1991, nr 5, s. 156-165. 
międzywojennego. Większość z opisywanych tu budynków w stopniu mniejszym lub większym nawiązuje do dziedzictwa architektonicznego miasta, przy czym najczęściej to fasada ma największe znaczenie, to ona nosi międzywojenną „maskę”. Dostrzec można stopniową ewolucję form: od imitacji - w projektach z lat dziewięćdziesiątych, do reinterpretacji - w projektach współczesnych. Część realizacji znajduje się bliżej jednego bieguna, część - bliżej drugiego, np. hotel Blick w sposób dużo bardziej dosłowny niż kamienica Moderna nawiązuje do form międzywojennej kamienicy mieszkalnej. Postmodernizm spopularyzował również stosowanie różnorodnych okładzin, zestawianie tradycyjnych form $\mathrm{z}$ nowoczesnymi materiałami oraz wkomponowywanie $\mathrm{w}$ fasadę elementów high-tech ${ }^{40}$. Podobne rozwiązania widoczne są w gdyńskich realizacjach łączących tendencję regionalizującą z technologiczną.

Regionalizm krytyczny jest alternatywną wobec postmodernistycznej praktyki kontekstualizacji nowoczesnej architektury ${ }^{41}$. Według twórcy tego pojęcia, Kennetha Framptona, architekci nie powinni szukać inspiracji w warstwie formalnej i stylistycznej miejscowej architektury, ale - jak pisze - „W takich lokalnych elementach, jak intensywność i jakość lokalnego światła, tektonika wyprowadzana $\mathrm{z}$ lokalnej struktury geologicznej lub topografii działki" ${ }^{42}$. Tego typu podejście zaobserwować można m.in. w projekcie Muzeum Miasta Gdyni i Marynarki Wojennej. Budynek został rozplanowany z uwzględnieniem różnicy poziomów gruntu. Bryła otwiera się na otaczającą przestrzeń, stanowi jej dopełnienie, a równocześnie rezygnuje $\mathrm{z}$ naiwnego naśladownictwa form zastanych.

Jak zauważa Piotr Winskowski, w połowie XX w. nastąpiła zmiana w zakresie związków pomiędzy architekturą a techniką, przejście od „konieczności” do „uzależnienia” ${ }^{43}$. Oznacza to, że technika przestała mieć wówczas znaczenie wyłącznie funkcjonalne, ale stała się dla architektów źródłem inspiracji formalnych. Jencks nazywa tendencje panujące $\mathrm{w}$ architekturze lat pięćdziesiątych i sześćdziesiątych „drugą estetyką maszyny” lub „późnym modernizmem”"4.

Współcześnie również można zauważyć dążenie do stosowania technologii nowej generacji - jest to tzw. „trzecia estetyka maszyny” ${ }^{45}$. Wraz z zanikaniem ograniczeń natury technicznej kreowanie form zależy w coraz większym stopniu od inwencji architekta i preferencji dewelopera, czego dowodem są atektoniczne, „rzeźbiarskie” realizacje dekonstruktywistów. Sławomir Gzell pisze, że „jest to architektura będąca »dziełem totalnym «, a więc taka, która powtarza się $\mathrm{w}$ wielu miejscach na świecie i nie potrzebuje przy tym uzupełnienia, jakim

40 Tarnowski, Transformacje..., s. 22.

41 Kenneth Frampton, W stronę krytycznego regionalizmu: sześć zasad oporu [w:] Teorie i manifesty..., s. 119-122.

42 Ibidem, s. 121

43 Piotr Winskowski, Modernizm przebudowany. Inspiracje technika $w$ architekturze u progu XXI wieku, Kraków 2000, s. 51.

44 Jencks, Architektura późnego modernizmu..., s. 7-8.

45 Winskowski, Modernizm przebudowany..., s. 174. 
Alicja jest użytkownik [...], jest jednocześnie muzeum i eksponatem" ${ }^{46}$. Architektura Melzacka współczesna ma wiele twarzy - dekonstruktywizm, minimalizm (zwany czasem nowym modernizmem) i architektura zrównoważona to tylko niektóre z nich.

Zarysowane tu w skrócie tendencje wpłynęły także na współczesną architekturę Gdyni. Dążenie do nadania jej technologicznego wyrazu widoczne jest w takich realizacjach, jak biurowce Baltic Business Center i City Arcade, które modyfikują i multiplikują formy wywodzące się z pierwszej estetyki maszyny (z zachodniego funkcjonalizmu oraz z konstruktywizmu). Jednakże elementy technologiczne $\mathrm{w}$ biurowcach $\mathrm{z}$ lat dziewięćdziesiątych, które pojawiały się głównie w elewacjach, miały charakter „nowoczesnego kostiumu” i niekoniecznie odpowiadały nowoczesnym rozwiązaniom wnętrza. $Z$ drugiej strony widzimy budynki prezentujące zupełnie nowy standard - przede wszystkim C.H. Kwiatkowski oraz Sea Towers. Każdy z nich wykazuje odmienne wpływy stylistyczne - od adaptacji form modernizmu zachodniego w pierwszym, po elementy dekonstruktywistyczne $\mathrm{w}$ drugim. W architekturze czerpiącej z techniki widać więc ciągłą ewolucję, choć najnowsze trendy zagraniczne nie są u nas jeszcze silnie rozpowszechnione. W Gdyni nie ma przykładów radykalnych realizacji dekonstruktywizmu, brak także architektury zrównoważonej, na światowym poziomie ${ }^{47}$.

Część terminologii architektonicznej wywodzi się z lingwistyki, której wpływ jest szczególnie widoczny w postmodernistycznym dyskursie architektonicznym. Słynny postulat „Domy chcą i muszą mówić” ${ }^{8}$ odzwierciedlał wiarę w to, że architektura komunikuje się z odbiorcą, i podejmował na nowo poszukiwania zainicjowane przez osiemnastowieczną architecture parlante. Zaczęły pojawiać się oryginalne realizacje o formach figuratywnych - tych ilustrujących funkcję budynku (np. restauracja Fishdance w Kobe, projekt: Frank Gehry, 1980) i tych o niejasnym przesłaniu, w myśl idei „,form follows fiction”49 (np. dom-twarz w Kioto, projekt: Kazumasa Yamashita, 1974).

Poprzez tendencję semiotyczną ${ }^{50}$ rozumiem stosowanie dosłownych, często wręcz naiwnych znaków-ikon. Do repertuaru tych znaków należą wszystkie

46 Sławomir Gzell, Wspótczesna architektura a tożsamość miast [w:] Architektura wspótczesna w mieście zabytkowym, red. Andrzej Zwierzchowski, Wrocław 2003, s. 27.

47 W Gdyni pierwszą realizacją przystosowaną do wymagań certyfikatu LEED ma być kompleks Waterfrontu, zob. http://www.propertydesign.pl/eko_trendy/120/waterfront_gdynia_zgodnie_z_wymogami_certyfikatu_leed,408.html [dostęp: 27.08.2014].

48 Charles Moore, Gerald Allen, Donlyn Lyndon, The Place of Houses, New York 1974, cyt. za: Przemysław Trzeciak, Historia, psychika, architektura, Warszawa 1988, s. 227. Por. także: Monika Kostaszuk-Romanowska, Narracje architektury od czasów postmodernizmu, „Białostockie Studia Literaturoznawcze" 2010, nr 1, s. 97.

49 Bernard Tschumi, I believe in placing architecture in the realm of ideas and invention, New York City, January 2004, by Vladimir Belogolovsky, Intercontinental Curatorial Project Inc., http:// curatorialproject.com/interviews/bernardtschumi.html [dostęp: 11.01.2015].

50 Słownikowa definicja semiotyki określa ją jako „teorię znaku w procesie porozumiewania się", por. Alan Cruse, Meaning in Language, an introduction to semantics and pragmatics, New 
formy związane z morzem i budową okrętu, czyli często spotykane we współczesnej architekturze Gdyni imitacje dziobów, ruf, masztów, relingów czy bulajów. Używam do określenia tej tendencji pojęcia semiotyczna, chociaż, by dokładniej oddać charakter relacji między formami architektonicznymi a ich przesłaniem, powinnam raczej zastosować określenie ikoniczna ze względu na to, że dosłowność tych form nawet u odbiorców nieznających kontekstu denotuje te same znaczenia ${ }^{51}$. Oczywiście budynki wykorzystujące ten dosłowny, ikoniczny system znaków mogą być $w$ dalszym ciągu interpretowane na zasadzie konotacji. Znający historię miasta odbiorca $\mathrm{z}$ łatwością zrozumie nawiązanie do morskiej przeszłości Gdyni.

Jaskrawym przykładem tendencji semiotycznej w gdyńskiej architekturze współczesnej jest budynek C.H. Batory, którego część imituje statek. Z kolei biurowiec City Arcade, oglądany pod odpowiednim kątem, zdradza podobieństwo do okrętu z nadbudówką. Charakterystyczny południowo-wschodni narożnik Muzeum Marynarki Wojennej wraz z południową elewacją gmachu budzą podobne, choć nie tak dosłowne skojarzenia.

Przykładem budynku, w którym wyraz znalazły wszystkie trzy opisane tendencje, jest Transatlantyk. Łączy on nawiązania do form modernizmu z lat trzydziestych ze stylizacją high-tech oraz elementami semiotycznymi (umieszczona na dachu imitacja komina statku z logo inwestora na przedzie). Obiekt ten jest poza tym ciekawym przykładem stopniowej dekonstrukcji form modernistycznych, co ujawnia się zwłaszcza wtedy, gdy zestawimy go z budynkiem ZUS-u i biurowcem Alfa Plaza.

Charakter współczesnej architektury gdyńskiej wynika z silnej potrzeby zaznaczenia tożsamości miasta i utrzymania ciągłości w jego architekturze. Rzeczywiście, na skutek operowania stosunkowo ograniczoną gamą środków wyrazu, architektura miasta tworzy spójną całość, co z pewnością jest zaletą Gdyni. Jednak wielokrotne i często naiwne powtarzanie popularnych, powszechnie akceptowalnych wzorców modernizmu należy ocenić jako zjawisko negatywne. Jak napisał Winskowski, „populizm estetyczny, łatwizna, średni poziom stylistyki i myśli jej towarzyszącej nigdy nie zapewnią rozwoju w jakiejkolwiek dziedzinie. [...] Takie podejście do działalności społecznej i artystycznej wobec stałego rozwoju techniki z czasem prowadzi tylko do dalszego rozdźwięku między dualistycznie ujmowanym światem emocji i intelektu" ${ }^{52}$. Choć słowa te dotyczą postmodernizmu, stanowią trafną wskazówkę dla kierunku rozwoju architektury w Gdyni.

York 2000, s. 7, http://www.scribd.com/doc/99626614/Meaning-in-Language-an-Introduction-to-Semantics-and-Pragmatics-Oxford-Textbooks-in-Linguistics [dostęp: 23.05.2014].

51 Znaki w ujęciu lingwistycznym dzielą się na ikoniczne oraz arbitralne. Według Charlesa Peirce’a te pierwsze są powiązane $\mathrm{z}$ ich znaczeniem poprzez podobieństwo, te drugie działają jedynie na zasadzie pewnej konwencji, zob. http://semiomiks.blogspot.com/2010/10/znak.html [dostęp: 23.05.2014].

52 Winskowski, Modernizm przebudowany..., s. 71-72. 
Alicja Melzacka

\section{Bibliografia}

Bańkowska Barbara, Urbanistyka i ja, Gdańsk 2012.

Cruse Alan, Meaning in Language, an introduction to semantics and pragmatics, New York 2000.

Frampton Kenneth, W stronę krytycznego regionalizmu: sześć zasad oporu [w:] Teorie i manifesty architektury współczesnej, red. Charles Jencks, Karl Kropf, Warszawa 2013, s. 119-122.

Ghirardo Diane, Architektura po modernizmie, Toruń 1999.

Graban Michał, Gdynia wobec przeobrażeń cywilizacyjnych XX i XXI w., Gdynia 2012.

Graban Michał, Tożsamość morska Gdyni wobec wyzwań epoki postindustrialnej [w:] Globalizacja i my. Tożsamość lokalna wobec trendów globalnych, red. Romuald Piekarski, Kraków 2003, s. 271-272.

Gzell Sławomir, Współczesna architektura a tożsamość miast [w:] Architektura wspótczesna w mieście zabytkowym, red. Andrzej Zwierzchowski, Wrocław 2003, s. 27-30.

Gzell Sławomir, Urbanistyka modernistyczna po cezurze II wojny światowej - przykłady Warszawy i Nowych Tych [w:] Wpływ dorobku II Rzeczpospolitej na urbanistyke i architekture powojenna, red. Witold Czarnecki, Białystok, 2013, s. 36.

Jaroszewski Tadeusz S., Piękne dzielnice. Uwagi o architekturze luksusowej w Warszawie w latach trzydziestych [w]: Sztuka lat trzydziestych. Materiały Sesji Stowarzyszenia Historyków Sztuki, Niedzica, kwiecień 1988, Warszawa 1991, s. 167-202.

Joć Iwona, O wspótczesnej architekturze Gdyni, „Pomerania” 2006, nr 1, s. 7-10.

Kostaszuk-Romanowska Monika, Narracje architektury od czasów postmodernizmu, „Białostockie Studia Literaturoznawcze” 2010, nr 1, s. 97-120.

Lorens Piotr, Plany rozwoju przestrzennego jako kontynuacja rozwoju międzywojennej wizji, „Renowacje i Zabytki” 2010, nr 4, s. 127-131.

Moore Charles, Allen Gerald, Lyndon Donlyn, The Place of Houses, New York 1974.

Olenderek Joanna, Modernizm w Gdyni - Modernizm w Łodzi. W poszukiwaniu odniesień stylistycznych $w$ architekturze [w:] Modernizm w Europie. Modernizm w Gdyni. Architektura I połowy XX wieku i jej ochrona, red. Maria Jolanta Sołtysik, Robert Hirsch, Gdynia 2011, s. 95-104.

Olszewski Andrzej K., Art déco i lata trzydzieste w Ameryce a sztuka europejska, Warszawa 2013.

Omilanowska Małgorzata, Nacjonalizm a style narodowe w architekturze europejskiej XIX i poczatku XX wieku [w:] Nacjonalizm w sztuce i historii sztuki 1789-1950, red. Dariusz Konstantynów, Robert Pasieczny, Piotr Paszkiewicz, Warszawa 1998, s. 146.

Omilanowska Małgorzata, Propaganda wizualna „Polski morskiej” [w:] Polska nad Battykiem. Konstruowanie identyfikacji kulturowej państwa nad morzem 1918-1939, red. Dariusz Konstantynów, Małgorzata Omilanowska, Gdańsk 2012, s. 9-17.

Piotrowski Piotr, W kregu dyskusji postmodernistycznych, „Artium Quaestiones” 1991, nr 5, s. 156-165.

Planting New Towns in Europe in the Interwar Years: Experiments and Dreams for Future Societies, red. Hellen Meller, Heleni Porfyriou, Newcastle upon Tyne, 2016.

The Post-Socialist City, Urban Form and Space Transformations in Central and Eastern Europe after Socialism, red. Kiril Stanilov, Dordrecht 2010. 
Sołtysik Maria Jolanta, Dzielnica reprezentacyjna Gdyni i jej powojenne oraz współczesne interpretacje [w:] Wplyw dorobku II Rzeczpospolitej na urbanistykę i architekture powojenna, red. Witold Czarnecki, Białystok 2013, s. 325-353.

Sołtysik Maria Jolanta, Gdynia miasto dwudziestolecia międzywojennego, urbanistyka i architektura, Warszawa 1993.

Sołtysik Maria Jolanta, Inspiracje międzywojenne we współczesnej architekturze Gdyni, „Architektura i Urbanistyka” 2008, nr 15, s. 43-57.

Sołtysik Maria Jolanta, Na styku dwóch epok. Architektura gdyńskich kamienic, Gdynia 2003.

Szczerski Andrzej, Modernizacje. Sztuka i architektura w nowych państwach Europy Srodkowo-Wschodniej 1918-1939, Łódź 2010.

Tarnowski Józef, Transformacje estetyczne architektury i urbanistyki w XX wieku, „Estetyka i Krytyka" 2002, nr 2(3), s. 85-106.

Teorie i manifesty architektury współczesnej, red. Charles Jencks, Karl Kropf, Warszawa 2013.

Trzeciak Przemysław, Historia, psychika, architektura, Warszawa 1988.

Tschumi Bernard, I believe in playing architecture in the realm of ideas and invention, New York 2004, https://curatorial.project.com/interviews/bernardtschumi.

Winskowski Piotr, Modernizm przebudowany. Inspiracje technika w architekturze u progu XXI wieku, Kraków 2000.

Wpływ dorobku II Rzeczypospolitej na urbanistykę i architekturę powojenna, red. Witold Czarnecki, Białystok 2013.

\section{Architecture after 1989 in Gdynia's City Centre in Relation to Modernist Tradition}

The following article explores the recurring stylistic tendencies in the architecture of Gdynia after 1989, and seeks to identify their origins. The study encompasses four distinguished areas in the city centre, and places emphasis on the relationship between the contemporary (and postmodern) architecture and the architectural legacy of Gdynia's inner city, which can be broadly defined as 'modernist'.

Based on a series of case studies, the Author has distinguished three intertwined architectural tendencies, each of them referring in their own way to the local context. Often manifested in the same architectural designs and, therefore, inseparable, these tendencies cannot be strictly delimited. They are: 'regionalist tendency' deploying architectural forms of the interwar origin, 'semiotic tendency' which perceives architecture as the system of signs, and 'technologising tendency' of which strive for the 'high-tech' appearance can be considered an ideological continuation of the modern imperative of progress.

To conclude, contemporary architecture in Gdynia represents, widely understood, contextualism: comprising all of the aforementioned tendencies. This status quo is reinforced by the strong need to maintain the continuity of the city's architecture, but also of its identity. As a result of operating with a relatively limited range of means of expression, architecture in Gdynia constitutes a coherent whole, which can be considered an advantage for the local landscape. Nonetheless, the notorious and often naive application of widely accepted patterns originating from the vocabulary of West European modernism, and the limitations inherent in that approach, should be definitely pointed out for further scrutiny. 